\title{
The Price of Public Action: Constitutional Doctrine and the Judicial Manipulation of Legislative Enactment Costs
}

\section{Citation}

Matthew Stephenson, The Price of Public Action: Constitutional Doctrine and the Judicial Manipulation of Legislative Enactment Costs, 118 Yale L. J. 2 (2008).

\section{Published Version}

http://www.yalelawjournal.org/images/pdfs/727.pdf

\section{Permanent link}

http://nrs.harvard.edu/urn-3:HUL.InstRepos:10849721

\section{Terms of Use}

This article was downloaded from Harvard University's DASH repository, and is made available under the terms and conditions applicable to Open Access Policy Articles, as set forth at http:// nrs.harvard.edu/urn-3:HUL.InstRepos:dash.current.terms-of-use\#OAP

\section{Share Your Story}

The Harvard community has made this article openly available. Please share how this access benefits you. Submit a story.

Accessibility 


\title{
THE YALE LAW JOURNAL
}

\author{
MATTHEW C. STEPHENSON
}

\section{The Price of Public Action: \\ Constitutional Doctrine and the Judicial Manipulation of Legislative Enactment Costs}

\begin{abstract}
A B S T RACT. This Article argues that courts can, and often should, implement constitutional guarantees by crafting doctrines that raise the costs to government decisionmakers of enacting constitutionally problematic policies. This indirect approach may implement a kind of implicit balancing of interests, in which the damage to constitutional values is weighed against the strength of the government's interest in the challenged policy, more effectively than alternative approaches. When the government has better information than the reviewing court about the effect of the challenged policy on constitutionally relevant interests, heightened enactment costs act as a kind of screening device: if the government would still enact a given policy in the face of substantial additional enactment costs, the probability that the policy serves significant government interests is likely to be higher. This Article first develops the theoretical argument as to how (and under what conditions) doctrines that manipulate legislative enactment costs may be more effective tools for judicial implementation of the Constitution than doctrines that require direct judicial assessment of the relative strength of the competing interests. The Article further contends that the federal judiciary already has the capacity to fashion doctrines that function in this way, and indeed current doctrine influences legislative enactment costs more than has generally been appreciated.
\end{abstract}

A U T H O R. Assistant Professor, Harvard Law School. I am grateful to Richard Fallon, Eugene Kontorovich, Daryl Levinson, John Manning, Jonathan Masur, John McGinnis, Martha Minow, Bob Powell, Mark Tushnet, Adrian Vermeule, and participants in the 2007 Harvard-Berkeley Conference on Constitutions \& Consequences for helpful comments on earlier drafts. 


\section{ARTICLE CONTENTS}

INTRODUCTION

I. THE THEORY OF ENACTMENT COST MANIPULATION

A. The Inevitability of Balancing and the Problem of Uncertainty 7

B. Enactment Costs and the Implementation of the Constitution 11

C. The Theory's Domain 16

1. Preferences 17

2. Information 19

3. The Social Costs of Enactment Costs 22

4. Implementability 24

II. THE PRACTICE OF ENACTMENT COST MANIPULATION 25

A. Expenditure of Material Resources $\quad 26$

1. Constitutional Liability Rules $\quad 27$

2. Procedural Safeguards 31

B. Statutory Drafting 33

1. Narrow Tailoring 34

2. Interpretive Presumptions and Clear Statement Rules 36

C. Legislative History $\quad 42$

1. Rewarding "Good" Legislative History: Analysis and Explanation Requirements

2. Penalizing "Bad" Legislative History: Impermissible Statements of Government Motive

D. Doctrinal Uncertainty

50

55

CONCLUSION

62 


\section{INTRODUCTION}

In the most famous sentence in all of American constitutional jurisprudence, Chief Justice Marshall declared, "It is emphatically the province and duty of the judicial department to say what the law is." susceptible of multiple readings, Justice Marshall's statement succinctly captures a particular view of how constitutional judicial review operates. According to this view, pervasive in much legal scholarship and commentary, some set of government actions is prohibited by "the law"; it is the duty of the courts to identify and to police the boundaries of that set; and anything that falls outside of the judicially defined set of prohibited actions is permissible. ${ }^{2}$ This Article contends that the focus on direct judicial assessment and enforcement of constitutional limits obscures important ways in which courts implement constitutional guarantees indirectly. Specifically, I argue that courts often can, do, and should craft doctrines that raise the costs to government decisionmakers of enacting constitutionally problematic policies, rather than attempting to designate certain government actions, or categories of government actions, as permissible or impermissible. ${ }^{3}$

1. Marbury v. Madison, 5 U.S. (1 Cranch) 137,177 (1803)

2. See, e.g., W. Va. State Bd. of Educ. v. Barnette, 319 U.S. 624,638 (1943) (declaring that the purpose of constitutional rights is "to withdraw certain subjects from the vicissitudes of political controversy, to place them beyond the reach of majorities and officials and to establish them as legal principles to be applied by the courts"); United States v. Butler, 297 U.S. 1, 62 (1936) (stating that a court's task when evaluating a constitutional challenge to a congressional statute is "to lay the article of the Constitution which is invoked beside the statute which is challenged and to decide whether the latter squares with the former"); see also Guido Calabresi, The Supreme Court, 1990 Term-Foreword: Antidiscrimination and Constitutional Accountability (What the Bork-Brennan Debate Ignores), 105 HARV. L. ReV. 8o, 82, 109-10 (1991) (claiming that "much of the academic constitutional law establishment" believes in a decisive judicial role in defining and enforcing constitutional rights against government action); Dan T. Coenen, A Constitution of Collaboration: Protecting Fundamental Values with Second-Look Rules of Interbranch Dialogue, 42 WM. \& MARY L. REV. 1575, 1578-79 $\&$ n.8 (2001) (discussing the prevalence of this all-or-nothing view of constitutional rights); Mark Tushnet, Alternative Forms of Judicial Review, 101 MICH. L. REV. 2781, 2781, 2784 (2003) (observing that traditional debates in U.S. constitutional law and theory are predicated on the belief that the United States has "strong-form" judicial review, in which the Supreme Court issues authoritative statements of what the Constitution requires that are absolutely binding on the other branches).

3. My argument is closely related to Professor Ernest Young's defense of the canon of constitutional avoidance as a "resistance norm" of constitutional law, which seeks to enforce constitutional values in a different manner than a more conventional "invalidation norm." See Ernest A. Young, Constitutional Avoidance, Resistance Norms, and the Preservation of Judicial Review, 78 TEX. L. REV. 1549, 1552 (2000) ("[N]ot all constitutional principles have a 'line in the sand' quality, such that all government acts short of that line are valid and all 
The advantage of this sort of indirect strategy, as compared with a categorical approach that seeks to classify government actions as lawful or unlawful, is that it may implement a kind of implicit balancing of interests. In that balancing, the damage to constitutional values is weighed against the strength of the government's interest in the challenged policy more effectively than under a direct judicial balancing test. When the government has better information than the reviewing court about the effect of the challenged policy on constitutionally relevant interests, heightened enactment costs act as a kind

government acts falling over that line are invalid. Rather, some constitutional principles take the form of 'resistance norms' - norms that may be more or less yielding to governmental action, depending on the strength of the government's interest [or other factors]."); see also $i d$. at 1594 (developing this point further). My position is also consonant with Professor Dan Coenen's conclusion that much of constitutional adjudication makes use of "semisubstantive" or "second-look" decision rules rather than all-or-nothing rules, see Coenen, supra note 2; Dan T. Coenen, The Rehnquist Court, Structural Due Process, and Semisubstantive Constitutional Review, 75 S. CAL. L. REV. 1281 (2002), as well as Professor Henry Monaghan's classic explication and defense of "constitutional common law," see Henry P. Monaghan, The Supreme Court, 1974 Term-Foreword: Constitutional Common Law, 89 HARV. L. REV. 1 (1975). The argument also builds on my earlier work, primarily in the administrative law context, on how procedural hurdles or explanatory requirements can provide costly signals to overseers about the underlying value that agents attach to their policy proposals. See Matthew C. Stephenson, A Costly Signaling Theory of "Hard Look" Judicial Review, 58 ADMIN. L. REV. 753 (2006) [hereinafter Stephenson, Costly Signaling]; Matthew C. Stephenson, The Strategic Substitution Effect: Textual Plausibility, Procedural Formality, and Judicial Review of Agency Statutory Interpretations, 120 HARV. L. REV. 528 (2006) [hereinafter Stephenson, Strategic Substitution]. Professor Jonathan Masur has recently suggested how a similar sort of screening mechanism may account for seemingly ineffective and expensive procedural requirements in the patent context and elsewhere. See Jonathan S. Masur, Process as Purpose: Administrative Procedure, Costly Screens, and Examination at the Patent Office (July 20, 2008) (unpublished manuscript, on file with author).

My argument is also connected to recent developments in the political science literature on delegation. Much of the delegation literature traditionally analyzed regimes in which a political principal defines some "discretionary window" in which an agent had absolute authority. See Jonathan Bendor \& Adam Meirowitz, Spatial Models of Delegation, 98 Am. Pol. SCI. Rev. 293 (2004); David Epstein \& Sharyn O'Halloran, Administrative Procedures, Information, and Agency Discretion, 38 AM. J. PoL. SCI. 697 (1994); Thomas W. Gilligan \& Keith Krehbiel, Organization of Informative Committees by a Rational Legislature, 34 AM. J. Pol. SCI. 531 (1990). More recent work has pointed out, however, that the principal would often do better by using a "menu law," in which the agent receives variable transfer payments (or avoids unpleasant sanctions or costs) that depend on the agent's choice. See Sean Gailmard, Discretion Rather Than Rules: Choice of Instruments To Constrain Bureaucratic Policy-Making, 17 Pol. ANALYSIS (forthcoming 2008); see also David P. Baron, Legislative Organization with Informational Committees, 44 AM. J. POL. SCI. 485 (200o) (discussing a similar control strategy in the context of congressional committees). This menu law strategy offers the principal more flexibility in fine-tuning the incentives of the agent, and so it is generally preferable so long as it is feasible for the principal. See Gailmard, supra. 
of screening device: if the government would still enact a given policy in the face of substantial additional enactment costs, the probability that the policy serves significant government interests is likely to be higher.

In a sense, this is a kind of constitutional law analogue to the well-known concept of "efficient breach" in contract law. ${ }^{4}$ It would be possible for courts to fashion contract law doctrines - presumptions, balancing tests, and the like - to help them determine which contractual provisions ought to be enforceable under what conditions, and to enforce these determinations through injunctions. The norm in contract law, however, is to compel the breaching party to pay damages. ${ }^{5}$ The logic is that the contracting parties usually have better information than the court about the relative economic values of breach and performance, so a liability rule is more likely to prevent inefficient breaches, while allowing efficient breaches. In a similar fashion, constitutional doctrines that raise the costs associated with problematic government enactments may help deter policies that are "inefficient" - in the broad sense of failing a hypothetical ideal constitutional balancing test-while allowing what might be thought of as "efficient breaches" of constitutional rights. ${ }^{6}$

This Article has two main objectives. Part I explains, as a theoretical matter, how, why, and under what conditions judicial doctrines that manipulate enactment costs may be more effective tools for judicial implementation of the Constitution than doctrines that require direct judicial assessment of the relative strength of the competing interests at stake. ${ }^{7}$ Part II argues that the federal judiciary already has the capacity to fashion doctrines that function in this way; indeed, current doctrine affects legislative enactment costs more than has generally been appreciated. Although manipulation of legislative enactment

4. See John H. Barton, The Economic Basis of Damages for Breach of Contract, 1 J. LEGAL STUD. 277 (1972); Robert L. Birmingham, Breach of Contract, Damage Measures, and Economic Efficiency, 24 Rutgers L. ReV. 273 (1970); Charles J. Goetz \& Robert E. Scott, Liquidated Damages, Penalties and the Just Compensation Principle: Some Notes on an Enforcement Model and a Theory of Efficient Breach, 77 COLUM. L. REV. 554 (1977).

5. Restatement (SECOND) OF CONTRACTS ch. 16, topic 3, introductory note (1981).

6. While the efficient breach analogy may be a useful heuristic in understanding the incentive effects of constitutional doctrines that alter government enactment costs, the two situations are different in several crucial respects. For example, in the contractual setting, the costs imposed on the breaching party are redistributed to the other party, which implies that the social costs of imposing the damages remedy are usually small. Typically, judicially-imposed government enactment costs do not involve a redistribution of wealth from the legislature to some other party, so the social costs of the enactment cost strategy in constitutional law will generally be higher.

7. For a general discussion of how judicial doctrines can be understood as mechanisms for implementing the Constitution, see Richard H. Fallon, Jr., The Supreme Court, 1996 TermForeword: Implementing the Constitution, 111 HARV. L. REV. 54 (1997). 
costs may not be the intended or primary effect of any doctrine in constitutional law, it is an important function of many such doctrines. Furthermore, some doctrines might be justified as means of manipulating legislative enactment costs, even if this was never their intended function.

Understanding both the theory of enactment cost manipulation and the ways in which existing constitutional doctrines may influence legislative enactment costs may be useful in evaluating the advantages and disadvantages of these doctrines, as well as in suggesting alternative doctrinal strategies for implementing the Constitution. By thinking more systematically about these issues, one may be able to craft doctrines that more effectively leverage the advantages associated with an enactment cost strategy while minimizing the inevitable shortcomings of such an approach.

\section{THE THEORY OF ENACTMENT COST MANIPULATION}

\section{A. The Inevitability of Balancing and the Problem of Uncertainty}

Constitutional review of government action pervasively, perhaps inevitably, requires some form of balancing. ${ }^{8}$ In virtually all hard constitutional cases, some privileged right, interest, or entitlement comes into conflict with a normatively attractive competing government interest. ${ }^{9}$ The need to balance constitutional values against competing interests is apparent in the text of some constitutional clauses, such as the Fourth Amendment's prohibition on "unreasonable" searches and seizures and the Fifth and Fourteenth Amendments' requirement of "due" process. Other clauses, such as the First Amendment's Speech and Religion Clauses and the Fourteenth Amendment's Equal Protection Clause, appear to embody more absolute prohibitions. But in practice, when defining the underlying right that is protected "absolutely" and in specifying the remedies available, courts have recognized the need to balance competing values and interests. ${ }^{10}$

8. See Richard H. Fallon, Jr., Individual Rights and the Powers of Government, 27 GA. L. REV. 343 (1993); Fallon, supra note 7; Kenneth L. Karst, Legislative Facts in Constitutional Litigation, 1960 Sup. Cт. Rev. 75, 78-80. But see T. Alexander Aleinikoff, Constitutional Law in the Age of Balancing, 96 YALE L.J. 943 (1987).

9. See Fallon, supra note 8; Stephen E. Gottlieb, Compelling Government Interests: An Essential but Unanalyzed Term in Constitutional Adjudication, 68 B.U. L. REv. 917 (1988); Symposium, Conference on Compelling Government Interests: The Mystery of Constitutional Analysis, 55 ALB. L. REV. 535 (1992).

10. See David L. Faigman, Reconciling Individual Rights and Government Interests: Madisonian Principles Versus Supreme Court Practice, 78 VA. L. REV. 1521, 1547-63 (1992); Fallon, supra 
This is not to assert that all constitutional doctrines involve some form of case-by-case, totality-of-the-circumstances balancing, nor that they should. As an empirical matter, pure balancing tests are relatively rare (though certainly not absent) in constitutional law. ${ }^{11}$ As a normative matter, scholars of various ideological stripes have argued against the wisdom of doctrines that call for judges to engage in all-things-considered, case-specific balancing. ${ }^{12}$ Yet in those areas in which courts reject case-by-case "retail" balancing of constitutional values and competing interests, they typically engage in a kind of "wholesale" balancing when formulating or refining their doctrinal approaches. ${ }^{13}$ For example, a judicial decision that a category of government action is presumptively lawful or unlawful, or that certain types of controversy are nonjusticiable, implicitly (and sometimes explicitly) rests on a judgment about how to strike the appropriate balance between some constitutionally protected value and the government's interest in advancing legitimate public policy objectives. ${ }^{14}$ Similarly, when courts decide that certain categories of government action will be subject to relatively forgiving "rational basis" review, while other categories will have to meet a more demanding level of scrutiny, these classification decisions typically involve probabilistic judgments about the likely costs and benefits of actions within the specified categories. ${ }^{15}$ Thus, rejection of retail balancing in individual cases generally implies wholesale balancing in the creation of doctrinal tests to implement constitutional guarantees.

To assert that constitutional adjudication and doctrinal formulation require balancing constitutional values against legitimate competing interests is to frame the problem faced by the courts, not to resolve it. How are courts to strike the appropriate balance? How are they to devise doctrinal frameworks that maximize the chances that an appropriate balance will be struck? This problem is especially acute given that courts face two well-known institutional

note 8, at 361-64; Karst, supra note 8, at 78-80; Daryl Levinson, Rights Essentialism and Remedial Equilibration, 99 COLUM. L. REV. 857 (1999).

11. See Fallon, supra note 7 , at 76 .

12. See Frederick Schauer, Playing by the Rules 135-66 (1991) (arguing in favor of rulebased decisionmaking on fairness, reliance, and efficiency grounds); Aleinikoff, supra note 8, at 972-95; Paul W. Kahn, The Court, the Community, and the Judicial Balance: The Jurisprudence of Justice Powell, 97 Yale L.J. 1, 56-6o (1987); Susan Rose-Ackerman, Against Ad Hocery: A Comment on Michelman, 88 Colum. L. ReV. 1697, 1700-02 (1988); Antonin Scalia, The Rule of Law as a Law of Rules, 56 U. CHI. L. REV. 1175 (1989).

13. See Fallon, supra note 8, at 361-65; Fallon, supra note 7, at 77-78.

14. See Faigman, supra note 10, at 1547-63; Fallon, supra note 8, at 361-64; Richard H. Fallon, Judicially Manageable Standards and Constitutional Meaning, 119 HARV. L. REV. 1274 (2006).

15. See Fallon, supra note 7. 
limitations. First, the federal judiciary's lack of direct electoral accountability raises questions about the extent to which courts may make value-laden judgments about the validity and relative importance of alleged constitutional rights and competing government interests. Alexander Bickel famously dubbed this legitimacy problem the "countermajoritarian difficulty," 16 and constitutional theorists have debated it ad nauseum for a half-century since. ${ }^{17}$

Even if one brackets or rejects the legitimacy objection to judicial review, courts still face a second institutional problem: their comparative disadvantage in gathering and evaluating information about the connection between policies and outcomes. It is not enough to assign normative weight to constitutionally protected values and competing government interests in the abstract. One must also assess the likely consequences of the challenged government action for those values and interests. ${ }^{18}$ Yet judges may not be especially good at making these sorts of empirical or predictive judgments, and that creates problems independent of the normative legitimacy of countermajoritarian judicial review. ${ }^{19}$

To illustrate the distinction between the legitimacy problem and the information problem, consider a stylized example. Imagine that a speaker in a public park is delivering a racist rant to a large crowd, and the police detain him pursuant to a statute that proscribes speech that is likely to incite racial violence. Now suppose (unrealistically) that the court reviewing the case could be certain that the probability that this speech (or this type of speech) would actually cause a race riot is fifteen percent. The example thus assumes away the court's information problem. The legitimacy problem remains, however. If the

16. Alexander M. Bickel, The Least Dangerous Branch: The Supreme Court at the Bar OF POLITICS 16-17 (1962).

17. See Barry Friedman, The Birth of an Academic Obsession: The History of the Countermajoritarian Difficulty, Part Five, 112 Yale L.J. 153 (2002); Barry Friedman, The Counter-Majoritarian Problem and the Pathology of Constitutional Scholarship, 95 NW. U. L. REV. 933 (2001).

18. See Karst, supra note 8, at 81, 84 .

19. See Archibald Cox, The Role of Congress in Constitutional Determinations, 40 U. CIN. L. REV. 199, 209 (1971); Neal Devins, Congressional Factfinding and the Scope of Judicial Review: A Preliminary Analysis, 50 DUKE L.J. 1169, 1178-82 (2001); Fallon, supra note 8, at 376. This information problem may arise because the professional background and training of judges, coupled with the comparative institutional insulation of the judiciary, makes courts systematically worse than a legislature or executive at assimilating empirical data and making factual predictions. The lack of electoral accountability may also mean the courts are more likely to err in assessing the impact of various statutory proposals on the welfare of relevant constituencies. But see Devins, supra, at 1182-86 (suggesting that, even if Congress has a superior institutional capacity to make predictive empirical judgments, it may lack appropriate institutional incentives to gather and use factual information appropriately). 
court were to hold that the statute is unconstitutional, one might reasonably ask why an unelected court is entitled to decide that a fifteen percent chance of a race riot is not high enough to prohibit inflammatory speech when the democratically elected legislature reached a different conclusion. Responding to this challenge is especially difficult if we concede that there is some point at which the risk of violence is so great that prohibiting the speech would be justified. (Imagine, again unrealistically, that the court knew with absolute certainty that this speech, if allowed, would trigger a city-wide race riot in which hundreds would die.) If we make that concession, then we have admitted the need for some sort of balancing. Yet how confident can we be that the court will strike the balance at the right point? Should a fifteen percent risk of a riot be sufficient to restrain speech? Five percent? Thirty percent? There are good reasons to worry about whether courts will assign the correct normative weight to the competing interests.

Now, consider a variant on the same example in which the legitimacy problem is assumed away but the information problem is present. Suppose that the court both would and should find the hypothetical statute unconstitutional as applied if, but only if, the probability that the targeted speech would incite a riot is less than twenty percent. That is, the government interest in public safety outweighs the speaker's autonomy and self-expression interests only if the probability of inciting a riot is greater than twenty percent. Even if there is no normative legitimacy problem with allowing the court to enforce that principle, the court is likely to be quite uncertain as to the true probability that the speech in question might cause a riot. Furthermore, even though the government, the defendant, and other interested parties might have better information on this point, they have an incentive to exaggerate in whichever direction favors their interests: the defendant's attorney will insist that the probability of this speech inciting violence was very low, while the government will insist that it was very high. The court will need to come up with some way to sift through the competing arguments and evidence and make the judgment that minimizes the aggregate error costs.

This simple pair of examples illustrates the conceptual distinction between concerns about courts' ability to correctly assign normative weight to constitutional values and competing government interests, and limitations on courts' capacity to evaluate the degree to which those values and interests are implicated by a given government action. In real life, the distinction is more elusive, and the degree to which a judicial decision or doctrine reflects a court's normative judgment about the relative importance of different interests, rather than an empirical prediction about the probable effect of the challenged policy 
on the relevant values, may not always be clear. ${ }^{20}$ Nonetheless, there is an important conceptual distinction between the objection that courts are unqualified to make value determinations (the legitimacy problem) and the objection that they are unqualified to assess (or predict) relevant facts (the information problem).

That distinction is important for purposes of this Article because the focus here is primarily on doctrinal solutions to the judiciary's information problem. As in the second version of the hypothetical hate speech case, the Article assumes away concerns about whether the courts assign the appropriate level of normative significance to various rights, values, and interests. This is not because these concerns are unimportant, nor because the judiciary's ability to make contested normative value judgments is unproblematic. But this Article's central arguments principally concern the doctrinal strategies that courts can employ to ameliorate their informational limitations. In exploring that issue, bracketing the legitimacy objection simplifies the analysis and exposition.

\section{B. Enactment Costs and the Implementation of the Constitution}

This Article's central claim is that judicial doctrines can raise the costs to legislators ${ }^{21}$ of enacting a given policy, thereby increasing the probability that policies subsequently enacted would satisfy a hypothetical ideal balancing test of constitutional values against competing government interests. The argument is not simply that judicial doctrines can reduce the total quantity of constitutionally problematic legislation by imposing an implicit tax on such legislation, though that is certainly one effect of doctrines that raise legislative enactment costs. Rather, I advance the stronger claim that judicial imposition of additional enactment costs on legislatures enables courts to reduce their comparative informational disadvantage. The better-informed government decisionmakers will only be willing to act when their true interest in the policy is sufficiently strong; government exaggeration of its true interest becomes a less viable strategy. Thus, courts may be able to approximate indirectly the outcomes that would be achieved by an ideal (but practically unimplementable) constitutional balancing test.

20. See David L. Faigman, "Normative Constitutional Fact-Finding": Exploring the Empirical Component of Constitutional Interpretation, 139 U. PA. L. REV. 541, 544, 546 (1991) (claiming that the "Court fails to distinguish between normative principles and empirical propositions" and noting the Court's traditional "casual interweaving of fact and law").

21. The same analysis applies to other government decisionmakers, including the President, law enforcement officials, and administrative agencies. The textual focus on legislative decisionmaking is purely for expositional convenience. 
The idea can be illustrated with another stylized example. Imagine that Congress is considering a statute that would advance some legitimate government interest but that would also injure some constitutional value. For concreteness, imagine a statute that would impose new regulatory obligations on Internet service providers. Proponents of the legislation justify it in terms of some legitimate public interest, such as eliminating online copyright infringement or protecting national security by blocking or monitoring the transmission of classified government information. The statute, however, may also threaten values protected by the Constitution, such as speech rights or privacy rights.

Securing passage of the statute requires effort on the part of supportive legislators and interest groups. This is true even for legislative proposals that are relatively simple and uncontroversial, and it is especially true for more complex or divisive proposals. The costs to legislators and interest groups of drafting and enacting legislation, other than the disadvantages of the legislation itself, are primarily opportunity costs. Legislators have limited time, staff, and political capital to allocate to a variety of activities, including not only legislation but also oversight, constituency service, campaigning, and public relations activities. A rational legislator will allocate her limited resources among these activities so as to maximize her ability to achieve her objectives, which will typically include reelection or career advancement, ideological or policy goals, prestige, and leisure. ${ }^{22}$ Therefore, when a legislator considers whether to work toward the enactment of a given bill, such as the hypothetical Internet regulation statute, she will consider not only how passage of that statute would benefit her, but also the opportunity costs of devoting resources to that bill rather than to other activities. Interest groups typically face a similar kind of tradeoff: effort devoted to securing the passage of any one legislative proposal is effort that cannot be devoted to some other valued activity. Legislation will be enacted only if a sufficient number of influential players believe that the net political and policy benefits associated with the legislation outweigh the opportunity costs of devoting sufficient effort to ensure passage.

Suppose that the benefits to legislators and interest groups of passing the hypothetical Internet regulation statute exceed the costs, so that the statute is enacted into law. The statute might then be challenged on constitutional grounds. If a court composed of omniscient judges were able to apply an ideal constitutional balancing test, it would uphold the statute if and only if the legitimate government interests in enacting the statute (such as fostering

22. See, e.g., Bruce Bueno de Mesquita et al., The Logic of Political Survival 21-23 (2003); Richard F. Fenno, JR., Home STYle: House MEMbers in Their Districts 137 (1978). 
innovation or defending against threats to national security) outweigh the injury to constitutionally significant values (such as speech and privacy). ${ }^{23}$ Alternatively, if the court were confident that the legislature would always fully internalize the costs and benefits of its decisions, then judicial review would be superfluous, because the court, even if not omniscient, would always uphold the decisions of the wise and benevolent legislature.

Problems arise, however, if the judiciary has incomplete information and the legislature has misaligned incentives. ${ }^{24}$ The legislature may undervalue the constitutional interests at stake-or, equivalently, it may overvalue the competing benefits. In other words, the private benefit of enacting the statute may exceed the private enactment cost for a sufficient number of legislators and interest groups, even though the social benefit of the statute is less than its social cost. When this is the case, the legislature may favor statutes that would fail the hypothetical ideal balancing test. If the reviewing court were omniscient, or at least had information as good as the legislature's about the statute's likely effects, the court could still constrain the legislature through the application of the ideal constitutional balancing test. But if the court's information about the issues at stake is not as good as the legislature's, the court's problem is much more difficult.

To illustrate, assume that the court can confidently assess the degree to which the hypothetical Internet regulation statute impinges on constitutionally privileged speech and privacy rights, but the court's information about the statute's relationship to competing government interests - intellectual property protection, national security, or what have you - is significantly worse than the legislature's. To make the information problem as stark as possible, albeit at the price of some descriptive realism, assume that the legislature (considered as a unitary actor $^{25}$ ) knows the public benefit of the statute with certainty even

23. The judge could do even better if she could credibly commit in advance to uphold only statutes for which the public benefits exceed the sum of the constitutional costs and the social opportunity costs of enactment. Credible commitment would be necessary because, at the moment the statute comes before the court, enactment costs are sunk.

24. Yet more problems arise if the judiciary has misaligned incentives and the legislature's information is no better than the court's. Serious as those problems are, I put them aside for purposes of developing this Article's central theoretical argument.

25. The theoretical difficulties with treating a multi-member body as a unitary decisionmaker are well known. See Kenneth J. Arrow, Social Choice AND Individual Values (1951); Richard D. McKelvey, Intransitivities in Multidimensional Voting Models and Some Implications for Agenda Control, 12 J. ECON. THEORY 472 (1976); Kenneth A. Shepsle, Congress Is a "They," Not an "It": Legislative Intent as Oxymoron, 12 INT'L REV. L. \& ECON. 239 (1992). This Article, however, neither assumes a single legislative intent or will, nor relies on the assumption that all members of the legislature have the same information. Rather, this Article assumes that 
though it may undervalue the constitutional interests at stake, while the reviewing court, despite having exactly the right values, can only make a rough estimate of the statute's impact on legitimate public interests.

If the reviewing court had to rely only on its own information, it would have to decide whether the expected public benefit of the statute-given the court's incomplete information-is greater or less than the cost to constitutional values. ${ }^{26}$ The court could apply a kind of retail balancing test or, alternatively, some other doctrinal formula that the court believes will achieve an appropriate constitutional balance at the wholesale level. But these approaches entail substantial error costs. The court's uninformed application of the relevant test may prevent the enactment of socially desirable, constitutionally justifiable legislation. After all, the true social benefit of the statute may be much larger than the court's estimate of the expected benefit. On the other hand, the court may end up approving a statute that inflicts an unjustifiably large injury to constitutionally protected values, if it turns out that the actual benefit of the statute is much lower than the expected benefit.

This dilemma is a well-known problem with judicial attempts to balance constitutional and other public values, whether at the retail level or the wholesale level. The question therefore arises whether there are better ways that the court can implement constitutional values, instead of a direct but uninformed inquiry into the effect of a challenged statute on constitutionally relevant values and interests. Is it possible for the court to establish doctrinal mechanisms that induce outcomes that more closely approximate those of a hypothetical ideal constitutional balancing test?

There are a number of ways that the courts might attempt to achieve such a result. One strategy targets the problem of misaligned legislative incentives, developing doctrines designed to induce greater legislative deliberation or to limit the influence of parochial interest groups. ${ }^{27}$ Another approach is to

the legislature employs some set of institutional arrangements that generate stable equilibrium policy choices, see, e.g., Kenneth A. Shepsle, Institutional Arrangements and Equilibrium in Multidimensional Voting Models, 23 AM. J. POL. SCI. 27 (1979), and that the equilibrium policy choice is affected by information that members of the legislature receive and process concerning the impact of various policies on some normatively relevant set of outcomes. Characterizing the legislature, or the enacting coalition, as a unitary actor that "knows" the effect of policies on outcomes and chooses the policy that would advance "its" interest is a shorthand way of describing this more complex collective choice process.

26. Again, if the court could commit to a decision rule ahead of time, it would uphold the statute only if the expected public benefit exceeded the sum of the constitutional costs and the social opportunity costs of enactment.

27. See Cass R. Sunstein, Interest Groups in American Public Law, 38 StAN. L. ReV. 29 (1985) (arguing that many constitutional doctrines can be understood as checking the power of 
establish doctrinal tests that elicit more accurate and credible information from the legislature about the public interests at stake, for example by demanding certain types of evidentiary showings or information disclosure. ${ }^{28}$ An alternative or complementary strategy, and the one on which this Article focuses, is to formulate doctrines that establish indirect mechanisms that credibly transfer information from the legislature to the court. One such approach is to increase the costs to the legislature of enacting constitutionally problematic legislation.

To see how this strategy could work, consider a case in which the legislature, though better informed than the court, systematically undervalues constitutionally privileged interests, or overvalues competing government objectives. Under this assumption, the private cost to legislators of enacting a given statute - the opportunity costs of enactment, plus the other perceived disadvantages of the law-may be smaller than the statute's social costs, including its impact on constitutional values. If, however, the opportunity cost of enacting the statute were to increase to the point at which the statute's private cost to a decisive legislative coalition were equal to the true social cost, then the legislature would never enact a statute with negative net social value. The legislature, however, would still pass the legislation if the private benefit to a decisive coalition were sufficiently high. Enactment costs thus function as a screening device, deterring legislative action with low private benefit to the legislature.

Because all legislative activity entails opportunity costs, some screening will take place even without judicial intervention. Furthermore, the legislative process laid down in Article I, Section 7 of the Constitution - which requires the assent of both houses of Congress plus the President, or two-thirds of each house if the President is in opposition - might itself be considered a device for raising the enactment costs of legislation, thereby helping to ensure that any legislation that makes it through this process is perceived by a sufficiently large number of legislators and interest groups not just as having some positive

parochial interests by inducing greater deliberation by legislatures); Cass R. Sunstein, Naked Preferences and the Constitution, 84 Colum. L. Rev. 1689 (1984) (arguing that much constitutional doctrine can be understood as a means to prohibit legislative action intended to benefit particular interest groups rather than to serve the public interest).

28. Cf. Eric A. Posner, Controlling Agencies with Cost-Benefit Analysis: A Positive Political Theory Perspective, 68 U. CHI. L. REV. 1137 (2001) (applying a model in which cost-benefit analysis entails disclosure of information about policy effects by a better-informed agent to a lessinformed political principal); Matthew C. Stephenson, Evidentiary Standards and Information Acquisition in Public Law, AM. L. \& ECON. REV. (forthcoming 2008) (considering how judicial demands for certain types of evidentiary showings affect government decisionmakers' incentives to acquire information). 
value, but as having substantial positive value. ${ }^{29}$ If the existing screen is not sufficiently powerful to filter out enough undesirable statutes, though, the courts can try to find ways to make the screen more demanding. One way for the courts to do this is by developing doctrines that raise enactment costs for those statutes for which the legislature is likely to overvalue the statute's benefits relative to its costs. The court's manipulation of legislative enactment costs enables it to extract more information from the legislature about the true public benefit of the statute in question. Even if the court cannot verify the government's assertions regarding the legislation's benefits, the magnitude of the enactment cost forces the government to credibly reveal some of its private information indirectly through its behavior. Judicial doctrines that raise the government's enactment cost thus increase the credibility of the government's assertion that it has a sufficiently strong interest in the legislation to justify the injury to constitutionally privileged values.

\section{The Theory's Domain}

In order for judicial doctrine to perform the hypothesized screening function described in the preceding section, four critical assumptions must hold. First, the relevant government policymakers' private interest in enacting a policy must be positively correlated (in expectation) with some normatively legitimate social interest, even though the government's interest in enacting the policy is systematically too strong. Second, the enacting legislative coalition must have better information about the expected impact of the policy than does the reviewing court, but the court must have reasonably good information about the enacting coalition's policy preferences. Third, the court must be able to fashion doctrines that increase the private opportunity cost of enactment for the decisive legislative coalition by more than these doctrines increase the social opportunity cost of enactment. Fourth, judicial doctrine must be capable of imposing enactment costs that are large enough to decrease the government's willingness to pursue the targeted class of policy decisions.

This Article does not claim that all of these assumptions always hold. Rather, the claim-more modest, but perhaps still controversial-is that they

29. This beneficial effect of the Constitution's cumbersome lawmaking procedure (as well as other "supermajority" rules) has been advanced and defended in a series of articles by John McGinnis and Michael Rappaport. See John O. McGinnis \& Michael B. Rappaport, Majority and Supermajority Rules: Three Views of the Capitol, 85 TEX. L. REV. 1115, 1128-37 (2007); John O. McGinnis \& Michael B. Rappaport, Our Supermajoritarian Constitution, 8o TEX. L. Rev. 703, 734-43 (2002); John O. McGinnis \& Michael B. Rappaport, Supermajority Rules as a Constitutional Solution, 40 WM. \& MARY L. REV. 365, 407-18 (1999). 
hold sufficiently often that a functionalist theory of judicial doctrine that focuses on manipulation of enactment costs is important to understanding and assessing the operation of real-world constitutional review. In order to better understand both the theory and the limits to its domain, I will elaborate on each of these four key assumptions.

\section{Preferences}

The first critical assumption is that the government's interest in a given policy is likely to be positively correlated with the true social interest in that policy, but also likely to be too strong. This assumption will hold when the government systematically undervalues constitutionally privileged interests, but not when the government is excessively hostile to those interests.

The critical distinction between undervaluation and hostility can be illustrated in the context of the Equal Protection Clause's restriction of racebased discrimination. Bracket for the moment debates about the legitimacy of distilling purposes or values from constitutional texts, as well as controversies about the scope and purpose of the Equal Protection Clause. Let us assume, for the sake of developing the distinction between undervaluation and hostility, that the central purposes of the Equal Protection Clause include the elimination of economic, political, and social subjugation of non-white minorities, as well as race-based stereotyping and stigmatization..$^{30}$ If these are the values the Equal Protection Clause is meant to advance, it is reasonable to suppose that the Southern legislatures that enacted Jim Crow legislation were hostile to these values. The very purpose of Jim Crow, after all, was to perpetuate the subordination and stigmatization of African Americans. The more effectively segregationist legislation achieved these goals - that is, the more effectively it subverted the values embodied by the Equal Protection Clause - the greater its appeal to a pro-Jim Crow legislature.

But not all government action that offends the Equal Protection Clause does so because the enacting officials are hostile to the Clause's values. Consider the California prison officials who decided to segregate prisoners on

30. Many scholars have argued that this, or something like it, is the most plausible understanding of the purposes of the Clause. See, e.g., LAURence H. TRIBE, AmERICAN Constitutional LAW 1514-21 (2d ed. 1988); Owen M. Fiss, Groups and the Equal Protection Clause, 5 PHIL. \& PUb. AfF. 107, 157 (1976); Cass R. Sunstein, The Anticaste Principle, 92 MICH. L. REV. 2410, 2429 (1994). This, of course, is a controversial position, but given that the example in the text is merely illustrative, it is not necessary for this Article to take a position on whether it is correct. 
the basis of race for their first sixty days in the state penal system..$^{31}$ These officials asserted that their goal was to reduce the risk of race-based prison violence, ${ }^{32}$ and there is little reason to doubt their honesty. Indeed, it seems implausible that these officials hoped by their actions to perpetuate the subordination of non-white minorities or the propagation of negative stereotypes about race. ${ }^{33}$ It is much more likely either that these officials gave no thought to how a presumption in favor of racial segregation would affect the dignity of non-white prisoners or the public perception of race as a predictor of behavior, or else that these officials believed such negative consequences would be outweighed by the benefits of reducing prison violence.

That does not make the prison segregation policy desirable or constitutional. It is quite possible that the prison officials, confronted as they were with the immediate and serious risks of violence, undervalued the constitutional interests safeguarded by the Equal Protection Clause. Insensitivity to these interests may well have led the state to enact an unjustifiable policy. But the problem in this case is undervaluation of the constitutional interest, not hostility to it. Evidence showing that the prison segregation policy would degrade the dignity of African-American prisoners more than had been previously supposed would almost certainly have made this policy less appealing, not more appealing, to the responsible officials.

The distinction between undervaluation and hostility is important, not least because it highlights the fact that not all, or even most, government threats to constitutional rights spring from hostility to constitutional values. ${ }^{34}$ The distinction is particularly important for the theory developed in this Article, because a judicial strategy that relies on increasing legislative enactment costs will be much more effective when the legislature undervalues constitutional interests than when it is hostile to them. In the former case, forcing the legislature to show that it is deeply committed to a policy is more likely to result in the enactment only of those decisions in which the constitutional values at stake really are outweighed by legitimate competing interests. In the latter case, intense legislative commitment to a particular

31. See Johnson v. California, 543 U.S. 499 (2005).

32. See id. at 502-03.

33. But see id. at 519 (Stevens, J., dissenting) (finding a "very real risk that prejudice (whether conscious or not) partly underlies the [state officials'] policy").

34. The injury to those values is not necessarily less severe when the cause is undervaluation rather than hostility, though there is an ongoing debate about the normative significance of "government purpose," on which this Article takes no position. See JoHN HaRT Ely, DEMOCRACY AND DistruST 105-79 (1980); Richard H. Fallon, Jr., Strict Judicial Scrutiny, 54 UCLA L. REV. 1267 (2007). 
policy may actually indicate that the injury to constitutionally privileged interests is especially severe. ${ }^{35}$

A closely related point is that in order for the enactment cost strategy to make sense, there must be a sufficiently close and positive relationship between the interests to which the legislature actually responds and the interests that can be legitimately balanced against constitutionally protected values. If, for example, the legislature is more likely to ban a particular kind of expressive conduct if that conduct tends to trigger violence, then raising the costs of enacting a statutory ban on such speech is more effective in limiting constitutionally problematic legislation to cases in which it is truly justified. If, on the other hand, the legislature's interest in passing the speech-restrictive statute is responsive only to normatively irrelevant or disreputable considerations, rather than to legitimate government interests, then an enactment cost strategy will be less effective. It may succeed in deterring some unjustifiable violations of constitutional rights, but it will not be a useful filtering or sorting mechanism.

Thus, one's assessment of the utility of the enactment cost strategy depends considerably on one's view of the performance of American political institutions. If one believes that these institutions, for all their faults, exhibit a reasonable degree of positive responsiveness to normatively defensible policy interests, then the enactment cost strategy is more sensible. The correspondence need not be perfect, nor need it arise because of any intrinsic benevolence on the part of policymakers. But, in order for the government's willingness to incur private enactment costs to signal something useful about the true public values at stake, the government's propensity to impinge on constitutional interests must be stronger, on average, when the legitimate government interests in doing so are more compelling. If one takes the more pessimistic view that the outputs of American policymaking institutions are generally unrelated to any normatively defensible concept of the public interest, then an enactment cost strategy's viability is greatly diminished, and perhaps eliminated.

\section{Information}

The second critical assumption of the theory concerns information: the legislature must have better information about the actual impact of the policy in question on relevant interests than does the reviewing court, but the court

35. Cf. Stephenson, Costly Signaling, supra note 3 (making this theoretical point in the analogous context of judicial "hard look" review of administrative agency decisions). 
must have reasonably good information about legislative preferences. If the government does not have superior information about policy effects, then there is no asymmetric information problem to solve. If the court does not have at least a rough sense of how government preferences and social preferences are misaligned, the court cannot compensate for this misalignment by adjusting legislative enactment costs.

Like the assumption that legislative interests are positively responsive to public interests, the assumption that legislatures or other government decisionmakers have better access to policy-relevant information implicates one's views about the overall performance of American political institutions. The more optimistic view is that, although the assumption of perfect information made in the stylized examples presented above is an obvious exaggeration, legislatures do typically make decisions on the basis of information that is not available to a layperson or a reviewing court. Legislators need not acquire this information directly, or even consciously process it. Responsiveness to information may instead take the form of input from staff, constituents, or interest groups. Nonetheless, in the optimistic view, legislative action is likely to reflect, at least on average, a more informed judgment about the connection between policy choices and actual outcomes. ${ }^{36}$

The more cynical view is that government policymakers either do not know or do not care about the connection between policy and outcomes. ${ }^{37}$ The assertion that they do not care is a claim about incentives, related to the earlier discussion concerning legislative responsiveness to public interests. The claim that they do not know reflects a belief that the issues are sufficiently complex, and the institutional means for information processing sufficiently poor, that policy decisions reflect sheer guesswork.

The accuracy of these contrasting visions depends in part on the nature of the policy issue, in part on the specific decisionmaker in question, and in part on additional issues beyond the scope of this Article. The important point is that a judicial strategy that focuses on manipulating legislative enactment costs is most likely to be effective when the legislature plausibly has better information about the connection between policy and outcomes than does the court. If the legislature's information is not likely to be much better than the court's, then the court may be better off doing the constitutional balancing directly (either retail or wholesale).

36. See, e.g., Cox, supra note 19, at 209-10; Louis Fisher, Constitutional Interpretation by Members of Congress, 63 N.C. L. ReV. 707, 722-25 (1985); Adrian Vermeule, Common Law Constitutionalism and the Limits of Reason, 107 COLUM. L. REV. 1482, 1507-11 (2007).

37. See Devins, supra note 19, at 1182-86. 
Of course, even if the legislature initially has better information than the court, the court may not need to use something like the enactment cost strategy. Perhaps the court can learn what the legislature knows through more direct means, such as demanding disclosure of relevant evidence. ${ }^{38}$ The problem with this strategy is that the courts may lack the necessary time or expertise to assess the evidence proffered by the government. Furthermore, if the legislature's decision is informed in the sense that it is responsive to the information of a diverse array of constituents and interest groups, there may be nothing tangible to disclose. Courts might also do their own research or rely on information from third parties, but again the institutional limitations of courts may preclude complete elimination of the informational asymmetry. The court's ability to reduce its informational disadvantage is likely to vary across different situations. The greater the court's ability to acquire relevant information directly, the less necessary or desirable the manipulation of legislative enactment costs will be as a means of extracting credible information. Such a strategy is most useful in cases in which the judiciary finds it impossible or excessively costly to acquire credible information from the legislature through more direct means.

Despite the judiciary's disadvantages with respect to information about the connection between policies and outcomes, the court must have reasonably accurate information about legislative preferences in order for manipulation of enactment costs to be a viable strategy. ${ }^{39}$ The court's information need not be perfect, but the more uncertain the court is about legislative preferences, the greater the error costs that doctrinal manipulation of enactment costs will entail. To make this abstract point more concrete, consider again the hypothetical Internet regulation statute. In order for an enactment cost strategy to be viable, the court's judgment as to whether the legislature typically overvalues national security or copyright protection relative to constitutional liberty must be better than the court's judgment of the statute's actual impact on the national security or intellectual property interests at stake.

This assumption will clearly not hold in all cases, but there are reasons to suppose it will often be plausible. First, because political or ideological considerations are likely to affect a large number of decisions, the court may have a larger number of data points from which to infer legislative preferences. Second, courts may be able to draw inferences about legislative preferences by

38. See Stephenson, supra note 28.

39. For similar reasons, the court also must have some sense of how different doctrinal requirements will affect legislative and social opportunity costs. Without such information, the court will not be able to determine what additional enactment cost, if any, would improve screening in a desirable way. 
observing structural features of the political system. For example, it may be reasonable to assume that legislative preferences will typically be biased in favor of politically powerful groups such as those with highly concentrated interests,$^{40}$ or in the direction of addressing highly visible or salient public concerns. ${ }^{41}$ Electoral pressures may also distort legislative efforts in the direction of short-term results or easily observable benefits. ${ }^{42}$

\section{The Social Costs of Enactment Costs}

The third critical assumption is that the court must be able to fashion doctrines that increase the private opportunity costs to policymakers more than the attendant social opportunity costs. As the earlier discussion noted, if legislators devote more time and energy to passing one piece of legislation, they have less time to devote to other tasks, such as work on other legislation, oversight activities, campaigning, constituency service, and leisure. ${ }^{43}$ Diversion of resources away from these activities is personally costly to legislators, which is why enactment costs can function as a screening device. But this resource diversion may be socially costly if the other activities that compete for legislative time and attention also serve the public interest. Thus, the valuable screening function that enactment costs may perform is not free. Although raising the legislature's enactment costs improves screening-making it less likely that the legislature will enact a statute that would fail an ideal balancing test-it also means that any statutes that are enacted will entail a higher social cost than they would have otherwise. ${ }^{44}$

Raising the legislature's enactment costs is only a desirable strategy if the additional private opportunity costs for the enacting coalition are sufficiently high relative to the additional social opportunity costs. Otherwise, the expected benefits of improved screening will be offset by the expected social costs of making legislative action more difficult. Furthermore, as long as at least some

40. See, e.g., Mancur Olson, The Logic of Collective Action (1971); Mancur Olson, The Rise AND DECLINE OF NATIONS (1982).

41. See Hugo Hopenhayn \& Susanne Lohmann, Fire-Alarm Signals and the Political Oversight of Regulatory Agencies, 12 J.L. ECON. \& ORG. 196 (1996); Cass R. Sunstein, The Laws of Fear, 115 HARV. L. REV. 1119 (2002) (book review).

42. See Ethan Bueno de Mesquita, Politics and the Suboptimal Provision of Counterterror, 61 INT'L ORG. 9 (2007); Susanne Lohmann, An Information Rationale for the Power of Special Interests, 92 AM. Pol. SCI. Rev. 809 (1998).

43. See supra text accompanying note 22 .

44. Of course, the social cost may be offset if the costly activities the court demands have additional public benefits that are not internalized by the legislature. 
of the legislature's private enactment costs represent social opportunity costs, the court will not want to increase enactment costs to the point at which the legislature would never pass a statute with negative social value. Instead, the court will tolerate some degree of incentive misalignment to avoid excessive expenditure of scarce legislative resources on any one statute.

All this indicates that an enactment cost strategy is less desirable when the other activities competing for legislators' attention are more socially valuable. If one believes that more work on securing passage of the hypothetical Internet regulation bill would come primarily at the expense of retail constituency service work or leisure time for legislative staff, then raising the enactment costs of the Internet bill may entail relatively low social opportunity costs. On the other hand, if devoting more effort to passing the Internet bill would divert resources from overseeing the implementation of existing statutes or securing passage of other valuable legislation, then raising enactment costs may impose significant social costs. ${ }^{45} \mathrm{~A}$ judicial strategy that involves some increase in enactment costs may still result in better expected outcomes than the court would achieve if it attempted to balance constitutional values against government interests directly, but the difference in relative desirability would be smaller.

There may appear to be some tension between the assumption that the legislature is positively responsive to legitimate public interests and the assumption that the social opportunity costs of legislative enactment efforts are relatively small. The former assumption seems to rest on an optimistic view of the legislative process, while the latter assumption appears to rest on a more pessimistic view that legislators devote much of their time and energy to activities with low social utility. The tension dissolves, however, if one makes the plausible assumption that although the legislative interest in any specific project is positively correlated (in expectation) with the social value of that project, the legislator's prioritization of various activities does not correspond to a socially optimal prioritization. This is analogous to stating that a firm manager's incentive to pursue a project is positively correlated with the profitability of that project for the firm, but also that the manager's allocation of effort across projects diverges from the allocation that would maximize the firm's profitability.

45. Cf. Ethan Bueno de Mesquita \& Matthew C. Stephenson, Regulatory Quality Under Imperfect Oversight, 101 AM. POL. SCI. REV. 605 (2007) (differentiating situations in which greater effort devoted to a given policy is socially costly from situations in which it is not). 


\section{Implementability}

The fourth critical assumption of the enactment cost theory is that courts are able to devise and implement doctrines that raise legislative enactment costs in meaningful and predictable ways. In general, courts cannot mandate additional enactment costs directly - they cannot, for example, impose a direct tax on legislators for allocating resources to particular bills. Instead, the main weapon available to the court is its power to strike down a law or policy. By conditioning judicial approval of a challenged law on whether the legislature has engaged in some set of costly activities, a reviewing court can raise legislative enactment costs. For this approach to work, however, two conditions must hold.

First, legislators must care about whether the statute is upheld by the court. There may be cases in which this condition fails. Legislators sometimes vote for statutes without knowing or caring whether those statutes will survive constitutional scrutiny; the symbolic political benefit of taking a position on some salient public issue may be all that matters. ${ }^{46}$ Furthermore, legislators may sometimes vote for a statute knowing, or even hoping, that the court will reject or limit it. That way, the legislators can take credit for a popular but illadvised statute without having to deal with the undesirable consequences of actually passing that statute into law. ${ }^{47}$

These caveats notwithstanding, it seems implausible to suppose that legislators are systematically indifferent to the fate of the statutes they pass. After all, excessive indifference to legal viability can be a risky political strategy. Sophisticated interest groups may well be aware of the doctrinal prerequisites for constitutional validity. They will not be satisfied by empty symbolism, and they will lobby for enactment of policies that will actually go into effect. Furthermore, the unsophisticated mass public may only care whether, at the end of the day, the problem the statute was meant to address was solved. Average voters may be difficult to appease through symbolic position-taking

46. See David R. Mayhew, Congress: The Electoral Connection 61-73 (1974).

47. See Eli M. Salzberger, A Positive Analysis of the Doctrine of Separation of Powers, or: Why Do We Have an Independent Judiciary?, 13 INT'L REV. L. \& ECON. 349, 361-64 (1993). A related argument is that legislators often prefer that the courts resolve controversial issues so that the legislators do not have to address these issues. See Mark A. Graber, The Nonmajoritarian Difficulty: Legislative Deference to the Judiciary, 7 STUD. Am. Pol. Dev. 35 (1993); Keith E. Whittington, "Interpose Your Friendly Hand": Political Supports for the Exercise of Judicial Review by the United States Supreme Court, 99 AM. POL. SCI. REV. 583 (2005). 
precisely because they are unsophisticated and uninformed. ${ }^{48}$ Having a statute struck down as unconstitutional may also reflect badly on the legislature, and it may embolden those legislators or constituencies that opposed the legislation in the first place. Finally, to the extent that legislators care about advancing a policy agenda, they will have an interest in enacting statutes that actually become law. Thus it is reasonable to suppose that there is a sizeable set of cases for which conditioning judicial approval on legislative enactment costs is likely to have an effect on actual government behavior.

The second condition is that the court must be able to establish, within the constraints of existing institutional arrangements, doctrines that actually raise the government's enactment costs. That is, the reviewing court must be able to impose conditions that the legislature must meet in order for a statute in a given class to be upheld, and these conditions must be credible, meaningful, foreseeable, and consistent with other features of American judicial and legislative institutions. This last condition is important here because the point of this Article is not to consider what sort of institutional arrangements might be possible if one were building a political-judicial system from scratch, but whether the existing federal judiciary has available doctrinal resources that are, or can be, used to better achieve an appropriate constitutional balance by raising legislative enactment costs. This issue is sufficiently important that I treat it separately in Part II.

\section{THE PRACTICE OF ENACTMENT COST MANIPULATION}

Part I argued that when four key assumptions hold, courts can improve the constitutional performance of government policymaking institutions by conditioning judicial approval of certain constitutionally problematic policies on the government's willingness to undertake activities that raise the costs of enacting those policies. Doing so screens out government actions with benefits that are low relative to their constitutional and other social costs, while allowing the government to take action with relatively high social benefits.

That, at least, is the theory. Does anything like this occur in practice? After all, courts typically do not speak in these terms, nor do most constitutional scholars. One of the challenges and intended contributions of this Article is to show that something like the enactment cost strategy is in fact much more

48. See Matthew C. Stephenson, Court of Public Opinion: Government Accountability and Judicial Independence, 20 J.L. ECON. \& ORG. 379, 393-94 (2004); Matthew C. Stephenson, "When the Devil Turns ... ": The Political Foundations of Independent Judicial Review, 32 J. LEGAL STUD. $59,62-63(2003)$. 
widespread in constitutional law than is generally acknowledged. As I will try to establish, the prevailing doctrinal approaches in many areas of constitutional law condition judicial approval on the willingness of legislators, or other government decisionmakers, to incur some substantial cost, over and above the "ordinary" cost of enacting a given policy. In some cases, it may be that these doctrines emerge, persist, and evolve largely because of their effect on enactment costs, even if they are not typically explained or defended in those terms. Furthermore, even if the effect of these doctrines on legislative enactment costs is entirely unintentional, the enactment cost theory might provide a normative justification for at least some of these doctrinal strategies, independent of their conventionally recognized effects. Focusing on the enactment cost justification for various doctrines may, in turn, suggest ways in which these doctrines ought to be refined or reformed.

This Part discusses four mechanisms through which constitutional doctrine might raise legislative enactment costs. First, constitutional doctrine might demand a direct government expenditure of material resources in order to eliminate a constitutional deficiency. Second, constitutional doctrine might impose onerous statutory drafting conditions, such as narrow tailoring or clear statement requirements. Third, constitutional doctrine might reward or penalize various forms of legislative history, making judicial approval easier when the desirable forms of legislative history are present and the undesirable forms are absent. Fourth, courts might devise constitutional doctrines that are unpredictable in their application, which from an ex ante perspective may have the same effect as an increase in enactment costs.

\section{A. Expenditure of Material Resources}

The natural place to begin is with those doctrines that expressly demand that the government expend material resources to eliminate or remedy a constitutional defect. Most obviously, some constitutional rules require the government to pay money to injured parties. Similarly, judicial doctrines that impose additional procedural requirements-either directly under the Due Process Clause or indirectly through doctrines that reward procedural formality with greater judicial deference - may require greater outlays from the public treasury. These effects will raise legislative enactment costs to the extent that the decisive coalition internalizes some of the costs associated with greater expenditures of public funds. 


\section{Constitutional Liability Rules}

Some constitutional rules raise the material resource cost to government of constitutionally problematic activities by requiring the government to pay compensation to injured parties. Of these, the most well known is the requirement that the government pay "just compensation" when it takes property for public use pursuant to the eminent domain power. ${ }^{49}$ There are arguably other constitutional liability rules as well, and some scholars have argued for broader use of liability rules, as opposed to "constitutional property rules," in other domains of constitutional law..$^{50}$ Constitutional liability rules, like other liability rules, are often defended as serving both an interest in compensation and an interest in deterrence..$^{51}$ In addition, constitutional liability rules, particularly the Just Compensation Clause, are sometimes defended on fairness grounds that go beyond the traditional interest in compensation. According to this argument, fairness requires that benefits to the general public be paid for by the general public rather than by a small number of disproportionately affected property owners. ${ }^{52}$

The compensation and fairness rationales for constitutional liability rules have no direct relationship to the enactment cost theory elaborated in Part I, but the deterrence rationale is a straightforward application of that theory. The familiar argument runs as follows: If the government does not have to pay compensation when it seizes private property, it will take property even when the benefit of the taking, as perceived by the government, is less than the benefit to the existing owners of retaining their property (as reflected in market prices). If, however, the government must pay just compensation, the

49. U.S. CONST. amend. V.

50. See Eugene Kontorovich, Liability Rules for Constitutional Rights: The Case of Mass Detentions, 56 StAN. L. ReV. 755 (2004) [hereinafter Kontorovich, Liability Rules]; Thomas W. Merrill, The Constitution and the Cathedral: Prohibiting, Purchasing, and Possibly Condemning Tobacco Advertising, 93 Nw. U. L. REV. 1143, 1157-65 (1999); cf. Eugene Kontorovich, The Constitution in Two Dimensions: A Transaction Cost Analysis of Constitutional Remedies, 91 VA. L. ReV. 1135 (2005) (arguing that constitutional liability rules are already more prevalent than is generally appreciated).

51. On the deterrence rationale, see Richard A. Epstein, BARgaining With THE STATE 84-85 (1993); Richard A. Posner, ECONOMic ANAlysis OF LAW 58-59 (7th ed. 2007); and William A. Fischel \& Perry Shapiro, Takings, Insurance, and Michelman: Comments on Economic Interpretations of "Just Compensation" Law, 17 J. LEGAL STUD. 269, 269-70 (1988). On the compensation rationale, see Kontorovich, Liability Rules, supra note 5o, at 759-60, 774.

52. See, e.g., Armstrong v. United States, 364 U.S. 40, 49 (1960) (stating that the purpose of the Takings Clause is to prevent the government "from forcing some people alone to bear public burdens which, in all fairness and justice, should be borne by the public as a whole"). 
government will take the property if and only if the monetized benefit of the taking to the government is greater than the market price. Thus, the compensation requirement allows socially efficient takings, in which the monetized public benefit exceeds the market price, but deters socially inefficient takings, in which the monetized public benefit is below the market price. $^{53}$

An important feature of the deterrence argument - and an important way in which it differs from the compensation and fairness rationales - is that the court could achieve the optimal behavioral result through injunctive relief if the court had accurate information about the social benefit of the proposed public use. If the court had such information, it could simply prohibit takings with negative net benefits and allow takings with positive net benefits, without requiring that any compensation be paid in the latter case. Likewise, the deterrence argument implicitly assumes that the government does not internalize the full social costs of the taking to the property owner (or, equivalently, that the government overvalues the benefits of the taking). If this were not so, then the government would take the property if and only if the true social benefit were greater than the true social cost, without any need for judicial intervention.

The deterrence rationale for a just compensation rule is therefore sensible only if we assume that the government is better informed than the court as to the consequences of the taking but gives insufficient relative weight to the interests of the property owners. Under these circumstances, a government left to its own devices would take property too often, while a court attempting to police takings through absolute injunctions would make frequent errors that allow too many, or too few, takings to occur. A compensation requirement, though imperfect, may induce better overall results because the increase in enactment costs may offset the government's excessive zeal for takings.

The fact that the enactment cost in this context takes the form of a transfer from the government to the injured party makes the strategy more attractive. Conceivably, we could achieve the same deterrence result simply by making the

53. An obvious but important objection is the Coasean argument that an absolute property rule-either that the government may take without compensation, or that the government may not take without the permission of the property owner-would achieve the same result when transaction costs are zero, because open-market bargaining will always cause the property to be assigned to the party that places a higher value on it. See Guido Calabresi \& A. Douglas Melamed, Property Rules, Liability Rules, and Inalienability: One View of the Cathedral, 85 Harv. L. ReV. 1089 (1972); R.H. Coase, The Problem of Social Cost, 3 J.L. \& ECON. 1 (1960). The literature on this argument is too vast to summarize here. I assume, for purposes of developing the argument, that there are many situations where transaction costs or market failures preclude efficient Coasean bargaining. 
government destroy an amount of public money equal to the market value of the seized property, but that approach would involve a pure deadweight social loss. $^{54}$ The transfer payment to the property owner does not eliminate the social cost of the taking because the compensation payment will require additional tax revenue, borrowing, or the diversion of resources from other government programs, but the deadweight loss component of the enactment cost will be proportionally smaller. ${ }^{55}$

A general problem with viewing this sort of monetary liability rule as an effective enactment cost strategy is that it assumes the government internalizes the costs associated with expenditures from the public treasury. Several scholars have observed, however, that governments do not act like profitmaximizing firms. ${ }^{56}$ Neither elected politicians nor bureaucrats are directly rewarded for how effectively they manage public revenues, especially when the government's capacity to run large budget deficits permits the legislature to operate under a relatively soft budget constraint. ${ }^{57}$ Furthermore, the amounts of money involved in compensating property owners are small relative to the government's overall budget, and the burdens of supplying the needed funds can be concentrated on politically weak groups either by raising their tax burden or by diverting funds from programs that would otherwise benefit those groups. ${ }^{58}$

These objections, while important, should not be overstated. While the federal government, as well as the governments of some states and large cities, may not be all that concerned about the amounts of public money that contemplated takings would require, many local governments are more financially constrained. ${ }^{59}$ Moreover, unlike the federal government, many states and localities are subject to balanced-budget requirements that give sitting legislatures and executives less freedom to shift costs to future years

54. This is a characteristic feature, and a recognized weakness, of this form of "money burning" signaling argument. See Stephenson, Costly Signaling, supra note 3, at 785-87.

55. Of course, it might be even more socially efficient if the government were compelled to pay the market value of the property not to the former owners, but rather to starving children (or some other socially worthy cause).

56. See Daryl J. Levinson, Making Government Pay: Markets, Politics, and the Allocation of Constitutional Costs, 67 U. CHI. L. ReV. 345, 345-48, 354-57 (200o); Louis Kaplow, An Economic Analysis of Legal Transitions, 99 HARV. L. REV. 509, 567-70 (1986); Edward Rubin, Commentary, Rational States?, 83 VA. L. ReV. 1433, 1439-42 (1991).

57. See Levinson, supra note 56, at 354-57.

58. See id. at $375-77$.

59. See Christopher Serkin, Big Differences for Small Governments: Local Governments and the Takings Clause, 81 N.Y.U. L. REv. 1624 (2006). 
(though state and local governments have found ways to circumvent some of these limits). ${ }^{60}$ And while government officials are not profit maximizers, they may well want to maximize some combination of political support and the achievement of specific policy objectives - and government money can be used to buy both of those things. ${ }^{61}$ A rational politician faced with the need to use some government money to compensate for a taking of property would try to raise this money in whatever manner is least disruptive of her political and policy goals, but the fact that she will rationally try to minimize the opportunity costs associated with a taking of property does not mean that those opportunity costs are zero.

Thus, the claim that monetary liability cannot function as an effective deterrent to inefficient takings-or, in the language I employ here, that monetary liability is not a meaningful enactment cost-seems overstated. That said, the amount of money that a legislature would need to pay to achieve "just compensation" often may not result in significant increases in legislative enactment costs because the legislature does not internalize the full social cost of the compensation payment, just as the legislature does not internalize the full social cost of the taking itself. Perhaps larger monetary liability would achieve the desired deterrence result, which raises the intriguing (though perhaps unrealistic) possibility that the government should be required to pay the former owner compensation well in excess of the property's market value. ${ }^{62}$ The fact that compensatory monetary liability may not achieve optimal deterrence further suggests the need to look at other ways that courts might raise the enactment costs of constitutionally problematic policy decisions, particularly those that involve costs that are more fully internalized by the enacting coalition.

6o. See D. Roderick Kiewiet \& Kristin Szakaly, Constitutional Limitations on Borrowing: An Analysis of State Bonded Indebtedness, 12 J.L. ECON. \& ORG. 62 (1996).

61. See Bueno de Mesquita et Al., supra note 22, at 8, 29-31, 58-59; John A. Ferejohn, Pork BARRel Politics 49-51 (1974); Gary S. Becker, A Theory of Competition Among Pressure Groups for Political Influence, 48 Q.J. ECON. 371 (1983); Arthur T. Denzau \& Michael C. Munger, Legislators and Interest Groups: How Unorganized Interests Get Represented, 8о АM. Pol. SCI. ReV. 89 (1986); Gene M. Grossman \& Elhanan Helpman, Protection for Sale, 84 AM. ECON. Rev. 833 (1994); see also Myriam E. Gilles, In Defense of Making Government Pay: The Deterrent Effect of Constitutional Tort Remedies, 35 GA. L. REV. 845 (2001) (responding to Daryl Levinson's critique of the deterrence rationale for making the government pay compensation).

62. The downside of this, however, is that the social cost of a larger transfer is likely to be greater. 


\section{Procedural Safeguards}

Requiring a direct payment to injured parties is not the only way that courts can raise the material cost of constitutionally problematic government enactments. Other doctrinal rules and principles may also raise the resource costs of certain policy decisions. For example, courts might invoke the Due Process Clause of the Fifth or Fourteenth Amendment to require the government to provide (costly) procedural safeguards before the government may interfere with certain constitutionally significant interests. Supreme Court case law on procedural due process has elaborated the sorts of procedural protections that are required for different forms of deprivation of liberty or property. ${ }^{63}$ Other constitutional provisions provide for more specific procedural protections for particular types of government action, such as the Fourth Amendment's warrant requirement and the Fifth Amendment's grand jury indictment requirement.

In addition to those constitutional rules that directly require some type of procedural formality, other constitutional doctrines indirectly encourage-or, in some cases, practically require - the government to use elaborate procedures in order to secure judicial approval for an otherwise constitutionally doubtful decision. In the takings context, for instance, the Fifth Amendment requires the government to establish that the taking is for a "public use." This requirement is particularly salient when the government transfers property between private parties. ${ }^{64}$ Whether the government used elaborate formal procedures in making the decision to take the property would not seem to bear any necessary relationship to the question of whether the taking serves a public use, yet Public Use Clause opinions sometimes emphasize this consideration. ${ }^{65}$ Similarly, in the nonconstitutional administrative law context, whether an agency used formal decision-making procedures in promulgating an

63. See Zinermon v. Burch, 494 U.S. 113 (1990); Cleveland Bd. of Educ. v. Loudermill, 470 U.S. 532 (1985); Carey v. Piphus, 435 U.S. 247 (1978); Mathews v. Eldridge, 424 U.S. 319 (1976); Fuentes v. Shevin, 407 U.S. 67 (1972).

64. See Kelo v. City of New London, 545 U.S. 469 (2005); Ruckelshaus v. Monsanto Co., 467 U.S. 986 (1984); Haw. Hous. Auth. v. Midkiff, 467 U.S. 229 (1984); Berman v. Parker, 348 U.S. 26 (1954).

65. See, e.g., Kelo, 545 U.S. at 484 (emphasizing the "comprehensive character of the [city's development] plan" and the "thorough deliberation that preceded its adoption"); $i d$. at 493 (Kennedy, J., concurring) (noting the city's compliance "with elaborate procedural requirements" as a reason not to apply a stricter standard of review to the city's taking and transfer of private property). 
interpretation of a statute is a central factor courts consider in deciding whether the agency's interpretation is entitled to deference. ${ }^{66}$

The conventional justification for constitutionally or judicially imposed procedural requirements is that they increase accuracy by correcting mistakes ex post and by encouraging government decisionmakers to be more thoughtful and careful ex ante. I do not dispute this benefit of procedural formality, though there is room for disagreement about how effective the sorts of procedures mandated by courts actually are in improving substantive accuracy. I want to suggest that in addition to whatever direct accuracy-improving or error-correction effects formal procedures may have, additional procedures also raise the material costs of certain government actions, whether that action is conducting a search, taking private property, terminating welfare benefits, or what have you. If the relevant government decisionmaker internalizes a significant portion of these resource costs, then judicial imposition of formal procedural requirements will increase enactment costs, with the potential screening results described in Part I. ${ }^{67}$

This separate effect is easier to see if we assume, counterfactually, that procedural formality has no direct effect on accuracy. If we make that assumption, then the only function that these procedures have (aside from whatever psychological or legitimacy benefits they may confer) is to increase the material cost to the government of taking the action that requires the use of procedures. This procedural cost may function as an enactment cost, deterring the government from taking action when the perceived net benefit to the government of the action is low, but enabling the government to take action when the perceived net benefit of the action to the government is high.

Again, my argument is not that this is the only effect of procedural formality. If it were, then some other costly activity, including burning money or buying food for starving children, would be just as effective at protecting constitutional values as requiring formal procedures (except insofar as procedural formality has some intrinsic constitutional value). The argument is that in addition to whatever benefits formal procedures have with respect to improving accuracy, they may also have the screening benefits associated with increasing enactment costs. The strength of this latter benefit is proportional to the degree to which the relevant government decisionmaker internalizes the costs associated with the additional formal procedures.

66. See United States v. Mead Corp., 533 U.S. 218, 229-31 (2001); see also Stephenson, Strategic Substitution, supra note 3, at $534 \mathrm{n} .14$ (advancing a rationalist explanation for why procedural formality affects judicial deference to agency legal interpretations).

67. See Masur, supra note 3 ; Stephenson, Strategic Substitution, supra note 3. 
This perspective on procedural requirements has at least two interesting implications. First, it implies that the marginal benefit of any given procedural safeguard may be higher than it would appear if only error-correction benefits were considered. To put the point in a slightly different way, the enactment cost perspective suggests that the marginal cost of additional procedures may be less than it might otherwise appear: While some of the additional procedural cost is indeed a social cost, some of that cost has a partially offsetting social benefit insofar as it more closely aligns government preferences with social preferences. Second, because of the screening effect, the set of cases that are actually subjected to the required formal procedures is likely to consist disproportionately of cases in which the government interest in taking the action is relatively strong. These observations together suggest that one might underestimate the net benefits of judicially imposed procedures if one neglects the enactment cost effect and looks only at cases in which the government decided to take the action that triggers the additional procedural safeguards.

That said, the concerns about the efficacy of direct monetary compensation apply to the use of costly procedures as well. If the responsible government decisionmakers do not internalize a substantial portion of the procedural costs, or if the procedural costs themselves are insignificant relative to the other costs and benefits at stake, then the effect of judicially imposed procedural formality on enactment costs may be trivial. This suggests that the marginal benefits of such procedural requirements are likely to be higher when they require the primary government decisionmaker to internalize significant costs than when they do not. It also suggests the importance of looking beyond material resource expenditures to other types of judicially imposed requirements that more directly raise enactment costs by imposing burdens directly on the government actors involved in promulgating constitutionally problematic policy decisions.

\section{B. Statutory Drafting}

Another way that courts can raise the enactment costs of constitutionally questionable policies is to impose drafting requirements that make promulgation of such policies more time-consuming and difficult. I will focus on two closely related drafting requirements that may have this effect. The first is the requirement that a statute be narrowly tailored to achieve some legitimate purpose. The second is the requirement that, in order to achieve certain constitutionally problematic results, the legislature must provide a clear statement of its intent. Narrow tailoring requirements and clear statement 
rules have many effects, but one effect common to both is an increase in the costs associated with drafting a statute to achieve a disfavored result.

\section{Narrow Tailoring}

Numerous constitutional doctrines, most notably in the areas of free speech, due process, and equal protection, demand that statutes be "narrowly tailored." ${ }^{\prime 8}$ The obvious and intuitive purpose of a narrow tailoring requirement is to reduce the problem of overinclusiveness, along with the attendant risk that an overbroad statute will be applied in an undesirable discriminatory fashion. ${ }^{69}$ Put another way, a narrow tailoring requirement may be a way to ensure that statutory restrictions are only applied in those cases in which the social benefits of these restrictions are high relative to the constitutional costs. Even if the aggregate benefits of a broadly worded statute would outweigh the aggregate costs, a court might still want to improve the cost-benefit ratio by eliminating, to the extent possible, those individual applications for which the costs exceed the benefits.

This does not completely explain why a court would strike down an entire statute on the grounds that it failed the narrow tailoring requirement. Even if the courts dispensed with the narrow tailoring requirement, they could accept case-by-case challenges to particular applications of the statute. This alternative approach has several drawbacks, however. Reliance on as-applied challenges may create substantial uncertainty for both regulators and potentially regulated parties, and it may also entail significant litigation costs for litigants and courts. It may therefore be more sensible for the court to insist that the legislature do the narrowing of the statute ex ante, rather than relying on the judiciary to address the overinclusiveness problem ex post. Doing so may lessen the

68. See Republican Party of Minn. v. White, 536 U.S. 765, 774-75 (2002); Reno v. ACLU, 521 U.S. 844, 846 (1997); Sable Commc'ns of Cal., Inc. v. FCC, 492 U.S. 115, 126 (1989); Ward v. Rock Against Racism, 491 U.S. 781, 798 (1989); New York v. Ferber, 458 U.S. 747, 769 (1982); Erznoznik v. City of Jacksonville, 422 U.S. 205, 215-17 (1975); Broadrick v. Oklahoma, 413 U.S. 601, 611-12 (1973); Shuttlesworth v. City of Birmingham, 394 U.S. 147, 150-51 (1969); Cox v. Louisiana, 379 U.S. 536, 551-52 (1965); Ian Ayres, Narrow Tailoring, 43 UCLA L. REV. 1781 (1996); Coenen, supra note 2, at 1823-28; Fallon, supra note 34.

69. See Forsyth County v. Nationalist Movement, 505 U.S. 123, 133 (1992); Ayres, supra note 68, at 1786; Coenen, supra note 2, at 1728; Eugene Volokh, Freedom of Speech, Permissible Tailoring and Transcending Strict Scrutiny, 144 U. PA. L. REV. 2417 (1996). 
aggregate social costs of reducing statutory overinclusiveness, and it will also shift those costs from courts and litigants to the enacting legislature. ${ }^{70}$

This last point about shifting the costs of tailoring the statute to the legislature suggests that a narrow tailoring requirement may also be a way for courts to raise legislative enactment costs, independent of the effect of the narrow tailoring requirement on how broadly the statute will actually apply. We can see this by considering a hypothetical case in which the narrow tailoring requirement has no effect on the scope of a statute's application in practice. Suppose that the legislature is considering a statute that prohibits publication of "information which would tend to undermine national security." On its face, the statute appears to sweep very broadly. Suppose, however, that we make the (unrealistic) assumption that in practice law enforcement officials would only apply the statute to some subset of the conduct that might conceivably violate the statute's broad terms. Call this subset $X$. Alternatively, we might define $X$ as the subset of applications that the court, applying the relevant doctrinal tests for as-applied constitutional challenges, would permit. Although the broadly worded statute appears to prohibit a large set of activities, its actual effect is to prohibit only conduct in subset $X$.

Now imagine that the Supreme Court imposes a narrow tailoring requirement that says the statute is unconstitutional unless the statutory language itself restricts application to subset $X$. By assumption, compliance with this narrow tailoring requirement would not narrow the actual application of the statute, because the conduct that the statute prohibits in practice is only subset $X$, with or without narrow tailoring of the statute itself. But the enactment cost to the legislature is higher under the narrow tailoring requirement, because the legislature has to try to determine the subset $X$ ahead of time, draft sufficiently detailed statutory language to define that set, and bear whatever opportunity and political costs are associated with engaging in that additional drafting activity.

The analysis in Part I suggests a reason why the court might want to impose a narrow tailoring requirement in such a case, even though the scope of the statute's practical application would not be affected. The court might worry that, although prohibiting conduct in subset $X$ might be justified by a sufficiently compelling interest, the legislature undervalues the constitutional concerns at stake relative to the competing government interests. But, the court might be aware that the legislature has better information about the actual

70. Cf. Louis Kaplow, Rules Versus Standards: An Economic Analysis, 42 DUKE L.J. 557 (1992) (discussing the salient differences between resolving questions about a law's application ex ante and ex post). 
effect of prohibiting the conduct in subset $X$. Even though the narrow tailoring requirement does not alter the scope of the statute's application in practice, it means the legislature will not bother enacting a narrowly tailored statute unless the benefits are sufficiently large. If the assumptions developed in Part I hold, then this narrow tailoring approach may be a sensible strategy for the reviewing court. $^{71}$

To be clear, my claim is not that narrow tailoring requirements do not alter the breadth of a statute's application if it is enacted. The preceding example made that assumption in order to clarify a separate and independent effect that a narrow tailoring requirement may have on legislative enactment costs. Seeing narrow tailoring doctrines in this light reveals their importance not only in cabining the scope of constitutionally problematic enactments, but also in ensuring that such statutes are justified by sufficiently weighty government interests. This suggests an additional reason why a court might prefer to impose a narrow tailoring requirement, rather than limiting statutory overinclusiveness through ex post judicial limitations on the scope of the statute's permissible applications.

\section{Interpretive Presumptions and Clear Statement Rules}

In addition to narrow tailoring mandates, courts can impose other requirements on the statutory drafting process that raise the enactment costs of constitutionally problematic policies. One common doctrinal technique with this effect is the so-called clear statement rule. ${ }^{72}$ When a court invokes a clear statement rule, it announces that it will not ascribe to statutory language a certain disfavored meaning unless the legislature has made that meaning

71. This argument is similar to, but distinct from, the claim that narrow tailoring requirements ensure "some measure of care and deliberation in the lawmaking process itself." Coenen, supra note 2, at 1728; see also Broadrick, 413 U.S. at 611-12 (suggesting this justification for the narrow tailoring requirement in the First Amendment context). The argument developed in this Article is not that narrow tailoring rules produce more careful and appropriate policy choices by forcing legislative reflection and deliberation, though that may well be one effect. Instead, the argument advanced here is that by raising the costs to legislators, narrow tailoring rules may implement a screening mechanism independent of any other effects on legislative reflection or consideration.

72. For general discussions of clear statement rules and related canons of statutory interpretation, see EINER ElHAUge, STATUtory Default Rules (2008); Coenen, supra note 2, at 1603-40; William N. Eskridge, Jr. \& Philip P. Frickey, Quasi-Constitutional Law: Clear Statement Rules as Constitutional Lawmaking, 45 VAND. L. REV. 593 (1992); and Cass R. Sunstein, Interpreting Statutes in the Regulatory State, 103 HARV. L. REV. 405, 451-60 (1989). 
unmistakably clear in the text of the statute. ${ }^{73}$ There are quite a few clear statement rules, many of which are explicitly designed to enforce constitutional values. Most obviously, under the modern version of the canon of constitutional avoidance, courts will construe statutes so that they do not raise difficult constitutional problems. That is, if Congress wishes to come close to the constitutional line, it must make its intention to do so clear. ${ }^{74}$ There are also a variety of more specific clear statement rules that seem designed to protect constitutional values through statutory interpretation. These include the presumptions against federal derogation of traditional state functions ${ }^{75}$ or abridgement of state sovereign immunity, ${ }^{76}$ and the narrow construction given to conditions on federal grants, ${ }^{77}$ which are all designed to protect federalism values; the rule of lenity ${ }^{78}$ and the presumption in favor of judicial review, ${ }^{79}$ which protect due process values; the tendency to construe statutes in ways that favor groups that are especially vulnerable to government discrimination,

73. It is important to emphasize that when a court refuses to adopt a particular reading of a statute because Congress has not endorsed that reading with sufficient clarity, the court is rejecting the reading that its other tools of interpretation would otherwise indicate is the best understanding of the text. Otherwise, the clear statement rule has no effect on the outcome.

74. See, e.g., Solid Waste Agency v. U.S. Army Corps of Eng'rs, 531 U.S. 159 (2001); Zadvydas v. Davis, 533 U.S. 678 (2001); Edward J. DeBartolo Corp. v. Fla. Gulf Coast Bldg. \& Constr. Trades Council, 485 U.S. 568 (1988); NLRB v. Catholic Bishop of Chi., 440 U.S. 490 (1979); Kent v. Dulles, 357 U.S. 116 (1958); see also William N. Eskridge, Jr., Public Values in Statutory Interpretation, 137 U. PA. L. REV. 1007, 1028-34 (1989) (discussing the judicial use of clear statement rules to protect constitutional values); Lisa A. Kloppenberg, Avoiding Constitutional Questions, 35 B.C. L. ReV. 1003 (1994) (same).

75. See Gonzales v. Oregon, 546 U.S. 243 (2006); Bates v. Dow Agrosciences LLC, 544 U.S. 431 (2005); Gregory v. Ashcroft, 501 U.S. 452 (1991); Rice v. Santa Fe Elevator Corp., 331 U.S. 218, 230 (1947).

76. See Raygor v. Regents of the Univ. of Minn., 534 U.S. 533 (2002); Hilton v. S.C. Pub. Rys. Comm'n, 502 U.S. 197, 204 (1991); Atascadero State Hosp. v. Scanlon, 473 U.S. 234 (1985); Employees of the Dep't of Pub. Health \& Welfare of Mo. v. Dep't of Pub. Health \& Welfare of Mo., 411 U.S. 279 (1973).

77. See Gonzaga Univ. v. Doe, 536 U.S. 273 (2002); Pennhurst State Sch. \& Hosp. v. Halderman, 451 U.S. 1 (1981).

78. See Chiarella v. United States, 445 U.S. 222 (1980); United States v. Universal C.I.T. Credit Corp., 344 U.S. 218, 221-22 (1952).

79. See Felker v. Turpin, 518 U.S. 651 (1996); Bowen v. Mich. Acad. of Family Physicians, 476 U.S. 667 (1986); Abbott Labs. v. Gardner, 387 U.S. 136 (1967); Daniel B. Rodriguez, The Presumption of Reviewability: A Study in Canonical Construction and Its Consequences, 45 VAND. L. REV.743 (1992). 
which advances the purposes of the Equal Protection Clause; ${ }^{80}$ the presumptions against extraterritorial legislation ${ }^{81}$ and against congressional derogation of the President's foreign affairs power, ${ }^{82}$ which safeguard presidential primacy in international relations; the presumption against retroactive deprivations of vested rights, which protects the property and liberty interests guaranteed by the Fifth Amendment as well as the interests safeguarded by the Contracts Clause $;^{83}$ and the judicial reluctance, at least in some instances, to read congressional delegations to executive branch agencies broadly, which may be a way of indirectly limiting congressional abdication of its Article I lawmaking responsibilities. ${ }^{84}$

Courts and sympathetic commentators typically justify the use of substantive, quasi-constitutional clear statement rules with one or more of four arguments. The first is the empirical claim that legislators are reluctant to intrude on the sensitive topics protected by the various clear statement rules. Thus, if the statute suggests but does not clearly require a meaning that would implicate the clear statement rule, it is probably the case that the members of the enacting legislative coalition did not intend or understand the statute to have that result. This is especially true if the provision at issue attracted little attention, debate, or opposition. ${ }^{85}$

The second argument in favor of clear statement rules is that they foster deliberation and careful consideration on constitutionally sensitive topics. Sophisticated legislators or interest groups will not be able to sneak something

8o. See INS v. Cardoza-Fonseca, 48o U.S. 421, 449 (1987); Bob Jones Univ. v. United States, 461 U.S. 574 (1983); McClanahan v. Ariz. State Tax Comm'n, 411 U.S. 164, 174 (1973); Eskridge \& Frickey, supra note 72, at 602, 610-14; Sunstein, supra note 72, at 473, 484.

81. See EEOC v. Arabian Am. Oil Co., 499 U.S. 244 (1991).

82. See Japan Whaling Ass'n v. Am. Cetacean Soc'y, 478 U.S. 221 (1986); Dames \& Moore v. Regan, 453 U.S. 654 (1981); Zemel v. Rusk, 381 U.S. 1 (1965); United States v. CurtissWright Exp. Corp., 299 U.S. 304 (1936).

83. See Martin v. Hadix, 527 U.S. 343, 358 (1999); Landgraf v. USI Film Prods., 511 U.S. 244 (1994); Winfree v. N. Pac. Ry. Co., 227 U.S. 296, 301 (1913).

84. See FDA v. Brown \& Williamson Tobacco Corp., 529 U.S. 120 (2000); Indus. Union Dep't, AFL-CIO v. Am. Petroleum Inst., 448 U.S. 607 (1980); John F. Manning, The Nondelegation Doctrine as a Canon of Avoidance, 2000 SuP. CT. ReV. 223; Cass R. Sunstein, Nondelegation Canons, 67 U. CHI. L. REV. 315 (2000).

85. See Spector v. Norwegian Cruise Line Ltd., 545 U.S. 119, 139 (2005) (plurality opinion); Rust v. Sullivan, 50o U.S. 173, 191 (1991); Pub. Citizen v. U.S. Dep't of Justice, 491 U.S. 440, 466 (1989); Lowe v. SEC, 472 U.S. 181, 206 n.50 (1985); Ex parte Endo, 323 U.S. 283, 300 (1944); James J. Brudney, Congressional Commentary on Judicial Interpretations of Statutes: Idle Chatter or Telling Response?, 93 MiCH. L. REV. 1, 79 (1994); Eskridge, supra note 74, at 1020-22. 
by a majority of the enacting coalition, nor will the legislature itself be able to sneak something by the voters. The demand for a clear statement, on this view, compels a greater level of transparency, deliberation, and accountability than would attend the ordinary legislative process. ${ }^{86}$

The third argument in favor of constitutionally derived clear statement rules appeals to a kind of judicial minimalism. ${ }^{87}$ Because clear statement rules, particularly the canon of constitutional avoidance, obviate the need to resolve a hard constitutional question by deciding the case on statutory grounds, these rules are thought to foster judicial modesty and moderation, as well as to preserve the courts' institutional legitimacy and authority and to limit conflict with the other branches of government. ${ }^{88}$

The fourth standard argument in favor of quasi-constitutional clear statement rules is more explicitly substantive, and perhaps for that reason it is less commonly articulated in judicial decisions. The argument goes something like this: The judiciary is charged with implementing duly enacted statutory law, but it is also charged with enforcing constitutional values. Courts have some authority to enforce constitutional values indirectly, by construing ambiguous statutes in ways that advance those values. This is not inconsistent with the judicial responsibility to enforce statutory law, because by definition an ambiguous statute is susceptible of multiple interpretations. ${ }^{89}$ So, the argument goes, if the legislature has failed to provide sufficiently clear commands, the courts may and should interpret those ambiguous commands so as to advance other substantive values that are derived from the Constitution. $^{90}$

86. See Spector, 545 U.S. at 139; United States v. Bass, 404 U.S. 336, 349 (1971); Greene v. McElroy, 360 U.S. 474, 507 (1959); Calabresi, supra note 2, at 104; Eskridge \& Frickey, supra note 72, at 631; Sunstein, supra note 72, at 471; Young, supra note 3, at 1608.

87. See generally Cass R. Sunstein, One Case at a Time: Judicial Minimalism on the Supreme COURT (1999) (arguing in favor of minimalist approaches to judicial interpretation).

88. See Almendarez-Torres v. United States, 523 U.S. 224, 238 (1998); Ashwander v. TVA, 297 U.S. 288, 345-48 (1936) (Brandeis, J., concurring).

89. See Young, supra note 3 , at 1588-93.

90. See Alexander M. Bickel \& Harry H. Wellington, Legislative Purpose and the Judicial Process: The Lincoln Mills Case, 71 HARV. L. Rev. 1, 34-35 (1957); Jane S. Schacter, Metademocracy: The Changing Structure of Legitimacy in Statutory Interpretation, 108 HARV. L. REV. 593, 652 n.308 (1995); Sunstein, supra note 72, at 459; Cass R. Sunstein, Law and Administration After Chevron, 9o Colum. L. Rev. 2071, 2112 (1990); Young, supra note 3. This justification for using something like the constitutional avoidance canon to enforce constitutional values is more prominent in countries that lack a written constitution. See T.R.S. Allan, Legislative Supremacy and the Rule of Law: Democracy and Constitutionalism, 44 CAMBRIDGE L.J. 111 (1985) (England); Aharon Barak, The Supreme Court, 2001 Term-Foreword: A Judge on Judging: The Role of a Supreme Court in a Democracy, 116 HARV. L. REV. 16 (2002) (Israel). 
Critics of substantive clear statement rules have attacked all of these justifications on a variety of grounds. ${ }^{91}$ This Article does not aspire to address or resolve these debates. Instead, it suggests that judicial demands for a clear congressional statement, in addition to whatever other effects they may have, can serve to increase legislative enactment costs for constitutionally problematic policies. This argument is similar to the last of the four justifications for constitutional clear statement rules sketched above. It differs, however, by emphasizing that the clear statement rule is a method for gauging indirectly the strength of the constitutional value relative to the other public interests at stake. ${ }^{92}$ This argument thus avoids the potential criticism of the more standard constitutional values position that such an approach would lead to overprotection of certain constitutional values at the expense of other legitimate public interests. The point of the avoidance canon and related clear statement rules, on this account, is not simply to enforce a constitutional value, but to assess the relative strength of competing government interests.

This argument parallels the earlier argument as to how narrow tailoring requirements can increase legislative enactment costs. Indeed, both narrow tailoring requirements and clear statement rules are, at bottom, judicial demands for greater precision in statutory drafting. Judicially devised clear statement rules and judicially imposed narrow tailoring requirements both require the enacting legislators and supportive interest groups to make a statute clearer if they want to achieve constitutionally problematic results. Producing this additional clarity raises the enactment costs for the coalition that supports the statute. ${ }^{93}$

91. See Richard A. Posner, Statutory Interpretation - in the Classroom and in the Courtroom, 50 U. CHI. L. ReV. 800 (1983); Frederick Schauer, Ashwander Revisited, 1995 SUP. CT. REV. 71.

92. Cf. EEOC v. Arabian Am. Oil Co., 499 U.S. 244, 262 (1991) (Marshall, J., dissenting) ("Clear-statement rules operate less to reveal actual congressional intent than to shield important values from an insufficiently strong legislative intent to displace them."); Young, supra note 3 , at 1552 (characterizing the constitutional avoidance canon as a "resistance norm" of constitutional law that "may be more or less yielding to governmental action, depending on the strength of the government's interest, the degree of institutional support for the challenged action, or the clarity of purpose that the legislature has expressed").

93. See Brudney, supra note 85 , at 30 (" [A]dding these details to text [to satisfy a judicial clear statement rule] increases the possibility for delay and obstruction even though the details themselves would command overwhelming support .... because each provision, clause, or word of a statute can become the focus of additional amendments or procedurally based attacks from a small but sufficiently determined minority."); Rodriguez, supra note 79, at 747 (" $[\mathrm{T}]$ he presumption of reviewability ensures that legislators must expend greater than normal costs to rebut this presumption ...."); Young, supra note 3, at 1597, 1608-o9 ("The effect of the presumption [in favor of judicial review] is that supporters of administrative nonreviewability in Congress must expend the time, effort, and political capital necessary 
As before, it is easier to see this effect if we assume that a clear statement rule neither reflects an accurate empirical judgment about legislators' preferences nor improves the quality of legislative deliberation. To illustrate, let us again suppose that the legislature is considering the hypothetical Internet regulation statute. The enacting coalition and its supporters understand that the version of the statute originally proposed would authorize government monitoring of Internet activity in ways that would raise constitutional questions related to speech and privacy. The statute is sufficiently ambiguous, however, that a court could plausibly read the statute not to allow this sort of intrusive electronic snooping, even though that is not the best reading of the statutory text.

Let us now consider three doctrinal regimes that the court might apply: one in which the court treats the electronic monitoring in question as constitutionally permissible, one in which the court treats it as prohibited, and one in which the court would hold that this sort of monitoring is permissible if the court were forced to address the question, but the court would avoid the constitutional question through statutory interpretation if possible. Let us also assume that the legislature can anticipate which approach the court will adopt.

Under the first regime, the legislature would pass the original version of the statute and the court would uphold the electronic searches as constitutional. Under the second regime, the legislature would either amend the statute to remove the offending provision or allow the court to invalidate it. Under the third regime, in which the court applies a clear statement rule, the legislature's choice is more complicated. The legislature could simply pass the statute as originally drafted, even though it knows that the court will adopt a strained interpretation that does not allow the problematic searches. Alternatively, the legislature could amend the statute to make explicit its authorization of electronic snooping. This latter approach would allow the intrusive electronic searches to go forward, but it would entail additional costs for the enacting coalition.

There are a few reasons why compliance with a clear statement rule might entail significant additional enactment costs. First, even if legislators and interest groups are generally aware that reviewing courts will apply the constitutional avoidance canon or some other clear statement rule, these interested parties need to figure out exactly how to draft the statutory language to secure judicial approval. This takes work, and this work has opportunity costs: the legislative aide or interest group staffer who is working on crafting language that will satisfy the clear statement rule is not doing other things.

squarely to confront the jurisdictional issue and formulate the needed clear statement of congressional intent."). 
Second, the need to get additional language into the bill provides one more opportunity for members of the enacting coalition to extract a price for their support and one more opportunity for opponents to obstruct or delay passage. Third, supporters of the constitutionally problematic provisions of the statute have only so much time and political capital. If they have to invest these resources in fashioning a sufficiently clear statement to satisfy the courts, they may have less ability to advance other aspects of their agenda. This is especially so if the clarity of the statement itself raises the profile, and hence the political salience, of the constitutionally problematic provisions.

If clearer statutory drafting is more expensive to members of the enacting legislative coalition and their supporters, then clear statement rules may raise enactment costs. Legislators and interest groups will be willing to bear these additional costs only if the statutory benefits internalized by the members of the enacting coalition are sufficiently high. If the four assumptions described in Part I hold, then the constitutional avoidance canon and other clear statement rules may help reviewing courts implement indirectly a regime that more closely approximates an ideal constitutional balancing test. Even if the interpretive canons applied by the court do not reflect an accurate empirical evaluation of legislative preferences, do not facilitate more deliberation, and do not appreciably reduce judicial activism, these canons may function as a screening device that helps to ensure that the legislature will not pursue constitutionally problematic policies unless the enacting coalition views those policies as sufficiently important.

\section{Legislative History}

Few issues in the theory and practice of statutory interpretation are as contentious as the debate over the proper role of legislative history. Any attempt to summarize this debate will oversimplify the more nuanced and sophisticated arguments for and against judicial use of legislative history in resolving statutory ambiguities. ${ }^{94}$ With that caveat, most of the contemporary

94. For a small sampling of the vast literature on this topic, see WiLLIAM N. ESKRIDGE, JR., DyNAMiC STATUTORY InTERPRETATION (1994); Bernard W. Bell, Legislative History Without Legislative Intent: The Public Justification Approach to Statutory Interpretation, 6o OHIO ST. L.J. 1 (1999); Stephen Breyer, On the Uses of Legislative History in Interpreting Statutes, 65 S. CAL. L. ReV. 845 (1992); Frank H. Easterbrook, Text, History, and Structure in Statutory Interpretation, 17 HARV. J.L. \& PUB. POL'Y 61 (1994); John F. Manning, Textualism as a Nondelegation Doctrine, 97 Colum. L. ReV. 673 (1997); Daniel B. Rodriguez \& Barry R. Weingast, The Positive Political Theory of Legislative History: New Perspectives on the 1964 Civil Rights Act and Its Interpretation, 151 U. PA. L. REV. 1417 (2003); Antonin Scalia, Common-Law Courts in a Civil-Law System: The Role of United States Federal Courts in Interpreting the 
discussion revolves around three questions. The first is the degree to which different types of legislative history are reliable evidence of some normatively legitimate conception of statutory meaning. ${ }^{95}$ The second question concerns the broader institutional effects that judicial use of legislative history may have on both the legislative process and the judicial process. ${ }^{96}$ The third question is whether judicial use of legislative history may be illegitimate for reasons independent of its probative value or practical consequences. ${ }^{97}$

Again, these debates are sufficiently complex that this Article cannot and does not aspire to engage them directly, nor does it take a final position on when, if ever, courts should employ various forms of legislative history in statutory interpretation. I make the more modest claim that viewing constitutional doctrine through the lens of enactment cost manipulation suggests ways that courts might use legislative history in order to implement indirectly an appropriate constitutional balancing test. If judicial willingness to

Constitution and Laws, in A MATter of InTerpretation: Federal Courts AND the LAW (Amy Gutman ed., 1997); Jonathan R. Siegel, The Use of Legislative History in a System of Separated Powers, 53 VAND. L. REV. 1457 (2000); Kenneth W. Starr, Observations About the Use of Legislative History, 1987 DuKE L.J. 371; Adrian Vermeule, Legislative History and the Limits of Judicial Competence: The Untold Story of Holy Trinity Church, 50 STAN. L. REV. 1833 (1998); and Patricia M. Wald, The Sizzling Sleeper: The Use of Legislative History in Construing Statutes in the 1988-89 Term of the United States Supreme Court, 39 AM. U. L. REV. 277 (1990).

95. See Wis. Pub. Intervenor v. Mortier, 501 U.S. 597, 620 (1991) (Scalia, J., concurring in the judgment); James M. Landis, A Note on "Statutory Interpretation," 43 HARV. L. ReV. 886, 888 (1930); McNollgast, Legislative Intent: The Use of Positive Political Theory in Statutory Interpretation, LAW \& CONTEMP. Probs., Winter 1994, at 3, 24. There is, in turn, an even more longstanding and complex debate over theories of statutory meaning. The three leading theories (really, categories of theories) are (1) intentionalism, which views the search for statutory meaning as a search for the intent of the enacting legislators; (2) purposivism, which seeks to identify a statutory purpose or set of purposes that may be different from or independent of the intention of any individual legislator; and (3) textualism, which posits that questions of statutory meaning turn on what the words of the statute would have been understood to mean by an objective reader of the statute familiar with the context in which it was enacted. See ESKRIDGE, supra note 94. Although criticism of the probative value of legislative history is often associated with textualism, while sympathy to the use of legislative history is usually associated with intentionalist or purposivist approaches, there is no necessary theoretical connection between these positions. It would be possible, for example, for a textualist to view legislative history as highly probative of how a reasonable person would have understood statutory language at the time it was enacted, while an intentionalist or purposivist might view certain forms of legislative history as highly unreliable guides to relevant forms of intention or purpose.

96. See Breyer, supra note 94, at 859; Elizabeth Garrett, Legal Scholarship in the Age of Legislation, 34 TUlSA L.J. 679, 685 (1999); W. David Slawson, Legislative History and the Need To Bring Statutory Interpretation Under the Rule of Law, 44 STAN. L. REV. 383, 407-10 (1992).

97. See Manning, supra note 94 . 
look to legislative materials beyond the text of the challenged enactment can raise the costs to the legislature of adopting constitutionally problematic policies, this can filter out government decisions that have low benefits relative to their constitutional costs. This argument differs from most of the conventional arguments for the use of legislative history in statutory interpretation, and it may therefore avoid some, though certainly not all, of the traditional criticisms.

Judicial attention to legislative history can influence legislative enactment costs in at least two ways. First, certain types of legislative history may be costly to produce: extended hearings, elaborate studies, reports, and the like. If reviewing courts evince greater skepticism of enactments that are not accompanied by elaborate supplementary materials of this kind, the courts may effectively raise legislative enactment costs. Second, while potential members of an enacting coalition may view some forms of legislative history as costly, they may view other forms as politically beneficial. For instance, politicians might trumpet the harm that a given enactment will inflict on an unpopular minority group in order to appeal to the prejudices of a majority. If reviewing courts demonstrate a greater willingness to invalidate enactments accompanied by "bad" legislative history, they may effectively raise the costs of such enactments because supporters will not be able to advertise, and may even have to disclaim, objectives that would be politically popular.

\section{Rewarding "Good" Legislative History: Analysis and Explanation Requirements}

When a reviewing court evaluates the legality of a government decision challenged on constitutional or other grounds, the court may consider whether the responsible government decisionmaker has developed an adequate explanation of the basis for its decision, often in the form of a record or report containing detailed evidence and analysis. The reviewing court may be more inclined to uphold a challenged action accompanied by such material, and in extreme cases the courts might treat development of a sufficiently detailed record as a prerequisite to the legal validity of the policy itself.

These sorts of explanation requirements are the norm in judicial review of administrative agency decisions. ${ }^{98}$ Although this approach is rarer and more

98. See Motor Vehicle Mfrs. Ass'n v. State Farm Mut. Auto. Ins. Co., 463 U.S. 29 (1983); Citizens To Preserve Overton Park, Inc. v. Volpe, 401 U.S. 402 (1971); Stephen Breyer, Judicial Review of Questions of Law and Policy, 38 ADMIN. L. REV. 363, 383 (1986); Sidney A. Shapiro \& Richard E. Levy, Heightened Scrutiny of the Fourth Branch: Separation of Powers and 
controversial in judicial review of legislative decisionmaking, there are numerous examples of cases in which the Supreme Court appears to have conditioned its approval of a constitutionally problematic legislative enactment on the quality of the legislative record. ${ }^{99}$ A particularly good illustration is the Court's approach to assessing the constitutionality of prophylactic legislation enacted pursuant to Section 5 of the Fourteenth Amendment. Section 5 grants to Congress "the power to enforce, by appropriate legislation" the substantive provisions of the Amendment, including prohibitions on state deprivations of equal protection or due process. ${ }^{100}$ The question of when Congress can invoke this power, particularly in the context of federal statutes that purport to abrogate state sovereign immunity from civil lawsuits, has proven difficult. The Supreme Court has held that the validity of a congressional invocation of Section 5 depends on the "congruence and proportionality" between the risk of constitutional violations and the legislative means adopted to prevent such violations. ${ }^{101}$ Although the Court has repeatedly denied that the quality of the legislative record is a significant consideration in evaluating whether federal legislation satisfies the congruence and proportionality test, ${ }^{102}$ in practice the

the Requirement of Adequate Reasons for Agency Decisions, 1987 DUKe L.J. 387, 411-13, 419-25; Stephenson, Costly Signaling, supra note 3, at 758-61.

99. For scholarly discussions of this phenomenon, see A. Christopher Bryant \& Timothy J. Simeone, Remanding to Congress: The Supreme Court's New "On the Record" Constitutional Review of Federal Statutes, 86 CoRnell L. ReV. 328 (2001); William W. Buzbee \& Robert A. Schapiro, Legislative Record Review, 54 STAN. L. ReV. 87 (2001); Coenen, supra note 2, at 1655-89; Ruth Colker \& James J. Brudney, Dissing Congress, 100 MiCH. L. Rev. 80 (2001); Devins, supra note 19; Philip P. Frickey, The Fool on the Hill: Congressional Findings, Constitutional Adjudication, and United States v. Lopez, 46 CASE W. RES. L. REV. 695 (1996); Philip P. Frickey \& Steven S. Smith, Judicial Review, the Congressional Process, and the Federalism Cases: An Interdisciplinary Critique, 111 YALE L.J. 1707 (2002); Harold J. Krent, Turning Congress into an Agency: The Propriety of Requiring Legislative Findings, 46 CASE W. Res. L. ReV. 731 (1996); Hans A. Linde, Due Process of Lawmaking, 55 Neb. L. ReV. 197, 22632 (1976); and Stephenson, Costly Signaling, supra note 3, at 794-80o.

100. U.S. CONST. amend. XIV, $\$ 5$.

101. City of Boerne v. Flores, 521 U.S. 507, 520 (1997).

102. See Fla. Prepaid Postsecondary Educ. Expense Bd. v. Coll. Sav. Bank, 527 U.S. 627, 646 (1999) (stating that "lack of support in the legislative record is not determinative" of whether Congress has exceeded its Section 5 powers); City of Boerne, 521 U.S. at 531 (stating that "lack of support in the legislative record" is not dispositive and that judicial deference to congressional judgments is "based not on the state of the legislative record Congress compiles"); Perez v. United States, 402 U.S. 146, 156 (1971) (noting that Congress is not required to "make particularized findings in order to legislate"). 
Court often points to the quantity and quality of evidence in the legislative record (or lack thereof) in making these determinations. ${ }^{103}$

Something like this approach also appears in some First Amendment speech cases, in which the Court has required Congress to present an adequate record showing the legitimacy of the purported government interest in imposing a speech restriction. In these cases, the question is typically whether the government's interest in the challenged speech restriction is sufficiently weighty in light of the applicable level of scrutiny. In deciding that question, the Court often looks to the evidence in the legislative record compiled by Congress in support of the legislation. ${ }^{104}$ As in the Section 5 cases, the Court disclaims any intent to treat Congress like an administrative agency by subjecting its record of decision to a kind of "hard look" review. ${ }^{105}$ But, as in the Section 5 cases, the Court often seems to do precisely that.

The focus on the quality of the legislative record shows up in equal protection jurisprudence as well, particularly in the affirmative action cases. ${ }^{106}$ Justice Powell, who wrote the controlling opinion in the seminal case Regents of the University of California $v$. Bakke, ${ }^{107}$ appears to have viewed the adequacy of legislative findings as particularly important. Justice Powell emphasized that although a race-conscious admissions program at a public university might be constitutional in the presence of adequate findings that such a program was necessary to advance a compelling state interest in remedying past racial discrimination, the California Board of Regents had not made such findings with respect to the admissions policy challenged in Bakke. ${ }^{108}$ Furthermore, in

103. See Tennessee v. Lane, 541 U.S. 509, 528-29 (2004); Nev. Dep't of Human Res. v. Hibbs, 538 U.S. 721, 730-32 (2003); Bd. of Trs. of the Univ. of Ala. v. Garrett, 531 U.S. 356, 368-69, 371 (2001); Kimel v. Fla. Bd. of Regents, 528 U.S. 62, 88-89, 91 (2000); Fla. Prepaid, 527 U.S. at $640,644,646$.

104. See Bartnicki v. Vopper, 532 U.S. 514, 530-31 \& n.17 (2001); Nixon v. Shrink Mo. Gov't PAC, 528 U.S. 377, 391-92 (2000); United States v. Playboy Entm't Group, Inc., 529 U.S. 803, 822 (200o); Turner Broad. Sys., Inc. v. FCC (Turner II), 520 U.S. 180, 196-213 (1997); Reno v. ACLU, 521 U.S. 844, 875 n.41, 879 (1997); Turner Broad. Sys., Inc. v. FCC (Turner I), 512 U.S. 622, 664-68 (1994); id. at 669 (Blackmun, J., concurring); Sable Commc'ns of Cal., Inc. v. FCC, 492 U.S. 115, 128-30 (1989); City of Renton v. Playtime Theatres, Inc., 475 U.S. 41, 60-62 (1986) (Brennan, J., dissenting).

105. See, e.g., Turner I, 512 U.S. at 665-66.

106. See Coenen, supra note 2 , at $1670-75$.

107. 438 U.S. 265 (1978).

108. Id. at 305 ("In this case ... there has been no determination by the legislature or a responsible administrative agency that the University engaged in a discriminatory practice requiring remedial efforts.”). 
his concurring opinion in Fullilove v. Klutznick, ${ }^{109}$ which upheld an affirmative action program for federal public works projects, Justice Powell emphasized the importance of formal congressional findings and legislative history that established the program was necessary to remedy past discrimination. ${ }^{110}$ More recent affirmative action decisions suggest that other members of the Court also view legislative findings as significant, though the opinions are somewhat opaque on this point. ${ }^{111}$

There are also examples of cases in which the Court might have adopted a doctrinal approach that emphasized the quality and comprehensiveness of the legislative record, but decided not to do so. The best illustrations are the Commerce Clause cases United States v. Lopez ${ }^{112}$ and United States v. Morrison. ${ }^{113}$ The Fifth Circuit's opinion in United States $v$. Lopez indicated that adequate congressional findings were necessary to deciding that a federal law criminalizing possession of firearms near schools was a valid exercise of Congress's power under the Commerce Clause. ${ }^{114}$ The opinion suggested the possibility that adequate congressional findings might lead the court to find no constitutional violation. ${ }^{115}$ In affirming the Fifth Circuit's holding, the Supreme Court also emphasized the absence of congressional findings of a substantial effect on interstate commerce. ${ }^{116}$ The Court, however, stressed that it would

109. 448 U.S. 448 (1980).

110. Fullilove, 448 U.S. at 502-03 (Powell, J., concurring); see also id. at 549-50, 552 (Stevens, J., dissenting) (arguing that congressional findings were inadequate to justify the program).

111. See Adarand Constructors, Inc. v. Pena, 515 U.S. 200, 220-21 (1995); City of Richmond v. J.A. Croson Co., 488 U.S. 469, 492, 500, 504, 510 (1989); id. at 520 (Kennedy, J., concurring); Wygant v. Jackson Bd. of Educ., 476 U.S. 267, 277 (1986); Miss. Univ. for Women v. Hogan, 458 U.S. 718, 730 \& n.16 (1982); Coenen, supra note 2, at 1673-75.

112. 514 U.S. 549 (1995).

113. 529 U.S. 598 (2000).

114. 2 F.3d 1342, 1362-64 (5th Cir. 1993). As support for this conclusion, the Fifth Circuit cited several Supreme Court cases in which, according to the Fifth Circuit, statutes had been "upheld against Commerce Clause attacks on the basis of formal Congressional findings .... [or] legislative history." Id. at 1362 (citing EEOC v. Wyoming, 460 U.S. 226, 231-232 \& n.3 (1983); FERC v. Mississippi, 456 U.S. 742, $755-56$ (1982); Hodel v. Va. Surface Mining \& Reclamation Ass'n, 452 U.S. 264, 277-79 (1981); Perez v. United States, 402 U.S. 146, 147 n.1 (1971); Katzenbach v. McClung, 379 U.S. 294, 298-300, 303-04 (1964)).

115. 2 F.3d at 1363,1368 (noting that when congressional findings of a substantial effect on interstate commerce are present, " $[\mathrm{p}]$ ractically speaking, such findings almost always end the matter," but declining to reach the question whether the legislation at issue might be sustained if accompanied by "adequate Congressional findings or legislative history").

116. Lopez, 514 U.S. at 562; see Coenen, supra note 2, at 1659-61; Robert F. Nagel, The Future of Federalism, 46 CASE W. Res. L. Rev. 643, 652 (1996); Cass R. Sunstein, Public Deliberation, Affirmative Action, and the Supreme Court, 84 CAL. L. REV. 1179, 1194 n.73 (1996). 
exercise its independent judgment in deciding whether a federal law had substantial effects on interstate commerce, and that congressional findings were only useful insofar as they aided the Court in making that judgment. ${ }^{117}$

The Court drove this point home in Morrison. In that case, Congress provided extensive hearing records and documentation in support of the assertion that the Violence Against Women Act's civil cause of action for gender-based violence would have a substantial effect on interstate commerce. ${ }^{118}$ The Supreme Court, however, dismissed these findings as irrelevant to the Commerce Clause analysis and reemphasized that the Court was to make an independent judgment regarding a statute's effects on interstate commerce. ${ }^{119}$ After the Supreme Court's decisions in Lopez and Morrison, it is not clear whether congressional findings have any significant effect on the probability that a purported congressional exercise of the Commerce Clause power will be upheld. ${ }^{120}$ But it is plain that the Supreme Court could have adopted, and may yet adopt, an approach more similar to the one that the Fifth Circuit adopted in Lopez, and that Justice Souter appeared to endorse in his Morrison dissent.

Judicially imposed evidence and analysis requirements are typically explained and justified with reference to two interrelated purposes. First, the government's decision-making record may provide the reviewing court with more substantive information about the strength of the government's interest, which the court can use to make its own independent assessment of whether the policy ought to be upheld. In other words, explanation requirements may be a way of mandating information transmission from the government to the court. ${ }^{121}$ Second, explanation requirements may assure the court that the government actually has made a decision on the basis of some degree of information and expertise. Even if the reviewing court cannot confidently

117. Lopez, 514 U.S. at 563 .

118. Morrison, 529 U.S. at $614 ;$ id. at 628-36 \& nn.2-9 (Souter, J., dissenting).

119. Id. at 614-15 (majority opinion); Coenen, supra note 2, at 1661-62.

120. See Gonzales v. Raich, 545 U.S. 1, 20-22 (2005); id. at 53-55 (O'Connor, J., dissenting); Coenen, supra note 2, at 1661-65 \& n.373.

121. This appears to be how the Supreme Court majority opinions in Lopez and Morrison view the relevance of congressional findings. See Morrison, 529 U.S. at 614-15 (stating that "the existence of congressional findings is not sufficient, by itself, to sustain the constitutionality of Commerce Clause legislation" and rejecting congressional findings that rely on an "unworkable" method of reasoning); Lopez, 514 U.S. at 562-63 (suggesting that congressional findings, though not required, may be useful in Commerce Clause cases when such findings "would enable [the Court] to evaluate the legislative judgment that the activity in question substantially affected interstate commerce, even though no such substantial effect was visible to the naked eye"). 
assess the government's explanation on the merits, it may be able to use the quality of that explanation to distinguish informed decisionmaking from uninformed decisionmaking. A more cynical alternative to these two explanations is that reviewing courts actually care little about the quality of the legislative record, and judicial statements (positive or negative) about the quality of the record are usually no more than makeweights. ${ }^{122}$

I do not deny any of these possibilities. What I want to suggest is that, in addition to whatever other functions may be served by judicial attention to the quality and quantity of the legislative record, this approach may also raise legislative enactment costs. Holding hearings, commissioning and presenting studies, providing evidence and explanation, instructing staffers to prepare elaborate analyses, and related activities all consume time and resources that could have been devoted to other things. ${ }^{123}$ The greater the quantity and quality of the supporting materials, the more time and resources will typically be required. Thus, the more significance a reviewing court attaches to the legislative record for a given decision, the greater the enactment costs of that decision are likely to be. This is true whether the requisite work is done by the legislators and their staffs or by outside interest groups, as they all face significant opportunity costs for this use of their time and resources.

If this is true, and if the other conditions for the enactment cost argument hold, then implicit or explicit judicial demands for a high-quality legislative record may help implement constitutional values, independent of any other function these requirements might perform. To put the point as starkly as possible, even if courts learn no verifiable information from the content of a legislative record, the mere fact that the enacting legislative coalition produced that record can provide the court with useful information about the strength of the government's interest. Again, I am not claiming that legislative record requirements perform no function other than increasing enactment costs, nor do I claim that influencing enactment costs is the conscious purpose of those courts that emphasize the quality of the legislative record. What I do argue is that when courts condition approval of constitutionally problematic legislation on the presence of costly legislative history, this has the effect of raising the government's enactment costs, and this in turn may perform the screening function described in Part I. The positive and normative debates over these sorts of doctrinal approaches are therefore incomplete if the effect on enactment costs is neglected.

122. See Coenen, supra note 2, at 1688-89, 1845-47; Mark Tushnet, Subconstitutional Constitutional Law: Supplement, Sham, or Substitute?, 42 WM. \& MARY L. REV. 1871, 1871-76 (2001).

123. See Daniel A. Farber \& Philip P. Frickey, The Jurisprudence of Public Choice, 65 TEX. L. ReV. 873,919 n.256 (1987). 


\section{Penalizing "Bad" Legislative History: Impermissible Statements of Government Motive}

The preceding examples involved cases in which the reviewing court rewarded legislators for providing "good" (but costly) explanations for constitutionally problematic decisions. There are also cases in which the courts appear to punish legislators for advancing "bad" explanations-that is, providing "bad" legislative history-for their policy choices. In addition to whatever other effects that judicial punishment of such explanations might have, this approach increases the government's enactment costs insofar as the judicially disfavored statements in the legislative history are politically beneficial to the relevant government decisionmakers.

Judicial attention to disfavored explanations for government policy choices is particularly notable in the context of the First Amendment's religion clauses. A persistent difficulty in enforcing both the Free Exercise Clause and the Establishment Clause, at least on their prevailing modern understandings, is the problem of distinguishing impermissible religious favoritism or hostility from permissible recognition of, or permissible interference with, religious beliefs or practices. When does recognition become favoritism? How do we know when the government has crossed the line separating legitimate policies that happen to burden certain religious practices from illegitimate policies that suppress or penalize particular religious beliefs? ${ }^{124}$

One approach that courts have used, when trying to draw these distinctions, is to look not only at the challenged government enactment, but also at what its supporters have to say about it. In numerous Establishment Clause cases, reviewing courts have looked beyond the challenged enactment itself to the rhetoric of the responsible government officials. Rhetoric in the legislative history (before or after enactment) suggesting hostility to religious minorities, or a desire to privilege particular religions or religion generally, may render the enactment more vulnerable to constitutional invalidation on Establishment Clause grounds. ${ }^{125}$ This approach also crops up in other

124. See Jesse H. Choper, Securing Religious Liberty: Principles for Judicial Interpretation of the Religion Clauses (1995); Daniel O. Conkle, Toward a General Theory of the Establishment Clause, 82 Nw. U. L. REV. 1113 (1988); Noah Feldman, From Liberty to Equality: The Transformation of the Establishment Clause, 90 CAL. L. REV. 673 (2002).

125. See McCreary County v. ACLU of Ky., 545 U.S. 844 (2005); id. at 881, 883-84 (O'Connor, J., concurring); Edwards v. Aguillard, 482 U.S. 578 (1987); id. at 597 (Powell, J., concurring); Wallace v. Jaffree, 472 U.S. $38,56-60$ (1985); $i d$. at 65 (Powell, J., concurring); $i d$. at 74-79 
constitutional contexts-most notably the First Amendment's Free Speech Clause and the Fourteenth Amendment's Equal Protection Clause, as well as other areas. ${ }^{126}$

Judicial attention to legislative history that evinces a desire to support or suppress religious practice, or some other disfavored purpose, is controversial. ${ }^{127}$ Several possible justifications for such attention are prominent in the literature and the case law. First, and most obviously, if one purpose of the First Amendment's religion clauses is smoking out bad government motives, legislative statements may be highly probative. A closely related argument turns on the claim that the primary harms the religion clauses are designed to prevent are symbolic or psychological: the feeling of exclusion or marginalization, along with the social divisiveness that may arise as a consequence of such feelings. ${ }^{128}$ If so, then government rhetoric is constitutionally relevant because such rhetoric directly affects the social meaning and understanding of legislative acts. ${ }^{129}$ Even if legislative rhetoric

(O'Connor, J., concurring in the judgment); Larson v. Valente, 456 U.S. 228, 253-55 (1982); McGowan v. Maryland, 366 U.S. 420, 453 (1961). Some Justices also appear to ascribe significance to the rhetoric of enacting legislators in determining whether the government has violated the Free Exercise Clause by targeting specific religious beliefs or practices for disfavored treatment. See Church of the Lukumi Babalu Aye, Inc. v. City of Hialeah, 508 U.S. 520, 540-42 (1993) (Kennedy, J.) (plurality opinion).

126. E.g., Hill v. Colorado, 530 U.S. 703, 719 (2000); id. at 768-69 (Kennedy, J., dissenting); Ward v. Rock Against Racism, 491 U.S. 781, 791 (1989); City of Cleburne v. Cleburne Living Ctr., Inc., 473 U.S. 432, 448 (1985); Hunter v. Underwood, 471 U.S. 222, 228-32 (1985); U.S. Dep't of Agric. v. Moreno, 413 U.S. 528, 534-35 (1973); see Paul Brest, The Conscientious Legislator's Guide to Constitutional Interpretation, 27 STAN. L. REV. 585, 589-94 (1975); Paul Brest, Palmer v. Thompson: An Approach to the Problem of Unconstitutional Legislative Motive, 1971 SUP. CT. ReV. 95; Coenen, supra note 2, at 1755-72; John Hart Ely, Legislative and Administrative Motivation in Constitutional Law, 79 YALE L.J. 1205 (1970); Richard L. Hasen, Bad Legislative Intent, 2006 WIS. L. REV. 843; Elena Kagan, Private Speech, Public Purpose: The Role of Governmental Motive in First Amendment Doctrine, 63 U. CHI. L. REV. 413 (1996).

127. See Church of the Lukumi Babalu Aye, 508 U.S. at 558-59 (Scalia, J., concurring in part and concurring in the judgment); Edwards, 482 U.S. at 636-39 (Scalia, J., dissenting); Palmer v. Thompson, 403 U.S. 217, 224 (1971); United States v. O’Brien, 391 U.S. 367, 383 (1968); McGowan, 366 U.S. at 466, 468-69 (Frankfurter, J., concurring); United States v. Constantine, 296 U.S. 287, 299 (1935) (Cardozo, J., dissenting); cf. Frank H. Easterbrook, Statutes' Domains, 50 U. CHI. L. Rev. 533, 547 (1983) (arguing against the use of legislative history in statutory interpretation generally).

128. A similar claim might be made regarding at least one of the purposes of the Equal Protection Clause.

129. See Wallace, 472 U.S. at 75-76 (O'Connor, J., concurring in the judgment); B. Jessie Hill, Putting Religious Symbolism in Context: A Linguistic Critique of the Endorsement Test, 104 MiCH. L. REV. 491 (2005). 
does not independently influence the social meaning of government acts, it may be probative as to how such acts are understood in the relevant community.

The enactment cost perspective developed in Part I does not directly engage the validity of these claims. Instead, it suggests a possible alternative or additional function that judicial penalization of "bad legislative history" may perform. One reason government decisionmakers often advertise the religious motivations behind a particular legislative or administrative act is because it is politically advantageous to do so. In many communities, legislators have an incentive to demonstrate their piety not only through rhetoric, and not only through government action, but through the conjunction of the two. The value of religiously inspired legislation is greatly reduced, however, if the enacting legislators are not allowed to invoke their support of that legislation as evidence of their religious convictions without jeopardizing the validity of the enactment itself. Forcing the legislators to abstain from pro- or anti-religious rhetoric when promulgating a constitutionally problematic decision may perform a screening function similar to that associated with doctrines that impose additional costly requirements. Here, instead of adding an enactment cost, the courts subtract an enactment benefit, which amounts to the same thing.

To illustrate, imagine that a state legislature is considering a bill that would prohibit businesses from opening on Sundays. ${ }^{130}$ The law will produce some benefits, both religious and secular. A Sunday closing law may provide a sense of religious solidarity for the Christian community, and it may encourage prayer and reflection. Designating one day a week as a mandatory holiday might also have a variety of non-religious benefits, and picking the day that most residents would customarily want to take off anyway is a sensible thing to do. On the other hand, a Sunday closing law will also produce costs. Some of these costs implicate the values and interests that the Establishment Clause, on some plausible accounts, is designed to safeguard. By affirming the significance of the Christian Sabbath and facilitating Christian religious worship, the Sunday closing law may place disproportionate burdens (both material and psychological) on non-Christians, which in turn could increase divisiveness along religious lines. ${ }^{131}$

130. See, e.g., McGowan, 366 U.S. 420.

131. As was the case with the Equal Protection Clause example, see supra text accompanying notes 30-31, this Article ascribes a set of purposes to the Establishment Clause in order to develop the example, but the Article does not take a position on whether this is in fact the best understanding of the Clause. 
A rational state legislator, acting in good faith, will try to balance these considerations. This legislator will also recognize that the political benefits from supporting the Sunday closing law are greater if she can claim, openly and adamantly, that she supported the law primarily out of a desire to honor and promote Christian religious beliefs. For purposes of developing the argument, let us take off the table the argument that by engaging in such rhetoric the legislator would alter the social meaning of the law so that it would have a more marginalizing and divisive effect. Let us further assume that there is nothing inherently objectionable about a desire to promote Christian solidarity and to encourage Sunday prayer, as long as other religious or secular groups do not suffer any significant harm. This assumption is obviously contestable, but I want to put to one side the argument that judicial attention to legislative rhetoric is appropriate because religious motivations are inherently illegitimate.

The legislator will support the Sunday closing law if the benefits, political and otherwise, exceed the costs. Suppose, however, that the legislator undervalues the costs associated with the marginalization of non-Christian citizens and the religious divisiveness that a Sunday closing law may foster. Again, I am assuming a legislator who is not hostile to these interests - she just does not care about them enough to strike the constitutional balance appropriately if left to her own devices. Finally, suppose that the reviewing court is not terribly good at evaluating the actual impact of the Sunday closing law. On this predictive question, the legislature is likely to have better information than the court.

This is simply another manifestation of the scenario developed in Part I. As the discussion in that Part demonstrated, the reviewing court might improve outcomes by raising the cost to the legislator of enacting the new law relative to retaining the status quo. One way for the court to do this is to make clear that it will uphold the Sunday closing law if but only if the enacting legislators abstain from making statements to the effect that they support the legislation because it recognizes and promotes Christian religious practices. The court might go further, requiring members of the enacting coalition expressly to disclaim any religious purpose for the law. Such a doctrinal approach would reduce the benefits legislators could expect to realize from passing the legislation. Those benefits, including the benefits associated with promoting observance of the Christian Sabbath, would not disappear, but the political benefits to enacting legislators would decrease because these legislators would not be able to point to their support of this legislation as evidence of their piety. By reducing legislators' ability to claim credit for certain popular aspects of the Sunday closing legislation, the legislation's political benefits will fall relative to its costs. This effect can bring the legislators' preferences more 
closely into line with the reviewing court's view of the appropriate constitutional balance. ${ }^{132}$

One appealing feature of this form of enactment cost strategy is that it may entail fewer deadweight costs than other approaches. Compelling a legislature to devote scarce resources to preparing elaborate records may divert resources from other socially valuable activities. Telling legislators that they must abstain from certain kinds of rhetoric may have considerably fewer social costs. I do not want to push this point too far, however. If we maintain our assumption that there is nothing inherently wrong with facilitating Christian worship, then there may be a social cost associated with preventing legislators from taking full credit for certain aspects of their policy decisions. More generally, encouraging politicians to be disingenuous may be socially costly, both by encouraging cynicism and by giving political leaders an incentive to expend resources in order to make sure their true motives and interests are communicated to relevant constituency groups in some other way.

The enactment cost argument for penalizing bad legislative history is not mutually exclusive with other justifications for this approach, such as the belief that statements by government officials shape the social meaning of government policy. But the enactment cost argument is independent of these other arguments. One might believe that the only constitutionally relevant consideration is the effect of the law, not the intent of the legislators, yet still

132. Although I have categorized enactment cost strategies that emphasize legislative history into those that reward "good" legislative history and those that punish "bad" legislative history, it would also be possible to classify these approaches in terms of whether they focus on the resource cost of the legislative history (where the enactment cost derives from the diversion of resources to producing the legislative history materials) or on the content of the legislative history (where the enactment cost derives from the political cost of foregoing, or including, certain types of substantive statements in the legislative history). In other words, what I have called "good" legislative history might be better characterized as "resourceintensive" legislative history, while what I have called "bad" legislative history might be better characterized as "politically advantageous position-taking." I use the "good" and "bad" classifications because these seem to track the judicial treatment of the different types of materials - resource-intensive explanations are perceived and characterized as good and useful efforts to establish the need for a particular enactment, while particular forms of politically advantageous position-taking, such as those discussed in the text, are viewed as evidence of bad motives. But this need not always be the case: if a court upholds legislation only if the legislative history contains an affirmative statement, such as the explicit disavowal of a religious motive for a Sunday closing law, then this might better be categorized as "rewarding good legislative history," even though the focus is on content rather than resource cost. And, of course, the resource cost and content effects may sometimes both be present, and may cut in opposite directions, as when a lengthy and detailed analysis of the justifications for a controversial enactment also contains politically expedient rationalizations. 
reach the conclusion that penalizing bad legislative history is an appropriate instrumental strategy for ensuring that those laws that are enacted are more likely to satisfy an ideal constitutional balancing test.

\section{Doctrinal Uncertainty}

Few judges or commentators have many kind words for unpredictability in constitutional doctrine. ${ }^{133}$ Indeed, the social costs of unpredictability are well known. When it is difficult to anticipate how a constitutional test will apply in different circumstances, the result may be underdeterrence (if parties have an incentive to push constitutional limits and courts are reluctant to sanction government conduct ex post) ${ }^{134}$ or overdeterrence (the "chilling effect" that can arise if parties are concerned about incurring serious penalties if their behavior is ruled unconstitutional). ${ }^{135}$ Unpredictability may also increase litigation costs, and some fear that insufficiently clear and determinate doctrine will allowindeed, encourage-judges to make constitutional rulings according to their subjective preferences regarding outcomes in individual cases. ${ }^{136}$ While there are many defenders of unpredictable legal standards, they do not typically defend unpredictability as such. Rather, they extol the virtues of flexible, context-sensitive doctrinal tests, and insist that the benefits of clear, predictable

133. See Richard H. Pildes \& Richard G. Niemi, Expressive Harms, "Bizarre Districts," and Voting Rights: Evaluating Election-District Appearances After Shaw v. Reno, 92 MicH. L. REV. 483, 537 (1993); Eric A. Posner \& Adrian Vermeule, Constitutional Showdowns, 156 U. PA. L. REV. 991, 1022 (2008); Rose-Ackerman, supra note 12, at 1700-02; cf. Gregory E. Maggs, Reducing the Costs of Statutory Ambiguity: Alternative Approaches and the Federal Courts Study Committee, 29 HARV. J. ON LEGIS. 123, 126-33 (1992) (discussing the costs of legal ambiguity in the context of statutory interpretation). But see Bruce Ackerman, The Emergency Constitution, 113 YALE L.J. 1029, 1042 (2004); Marc R. Poirier, The Virtue of Vagueness in Takings Doctrine, 24 CARDOZO L. ReV. 93, 100-03 (2002); Mike Schaps, Vagueness as a Virtue: Why the Supreme Court Decided the Ten Commandments Cases Inexactly Right, 94 CAL. L. REV. 1243, 1244-45, 1265-68 (2006).

134. See Marin R. Scordato \& Paula A. Monopoli, Free Speech Rationales After September 11th: The First Amendment in Post-World Trade Center America, 13 STAN. L. \& POL'Y REV. 185, 188 (2002).

135. See Auvil v. CBS 6o Minutes, 67 F.3d 816, 822 (9th Cir. 1995); Michael A. Lawrence, Toward a More Coherent Dormant Commerce Clause: A Proposed Unitary Framework, 21 HARV. J.L. \& Pub. POL'Y 395, 398-99 (1998); Rose-Ackerman, supra note 12, at 1701 \& n.29; Case Comment, Kelo v. City of New London, 119 HARV. L. ReV. 287, 293 (2005); Julian Cyril Zebot, Note, Awakening a Sleeping Dog: An Examination of the Confusion in Ascertaining Purposeful Discrimination Against Interstate Commerce, 86 MINN. L. REV. 1063,1066 (2002).

136. See, e.g., Scalia, supra note 12. 
constitutional doctrines come at too steep a price. ${ }^{137}$ Many would therefore view Mark Tushnet's conclusion that "clarity is a virtue that cannot be valued too much in constitutional law" ${ }^{138}$ as only a slight exaggeration.

Despite this, many areas of constitutional law are rife with uncertainty. Consider, as one of a number of possible illustrations, dormant Commerce Clause doctrine, especially with respect to state laws that do not overtly or intentionally discriminate against out-of-state entities. While state laws that facially discriminate against out-of-state entities are presumed to be unconstitutional unless the state interest is compelling, ${ }^{139}$ even a statute that does not facially discriminate against interstate commerce may run afoul of the dormant Commerce Clause if "the burden imposed on such commerce is clearly excessive in relation to the putative local benefits." ${ }^{140}$ This may sound straightforward, but in practice the application of dormant Commerce Clause doctrine is confusing and unpredictable. ${ }^{141}$ The result of this uncertainty, many argue, is that states are deterred from engaging in a variety of regulatory activities. ${ }^{142}$

Another example of an area of constitutional law plagued by uncertainty concerns the use of race as a factor in drawing legislative districts. In Shaw v. Reno ${ }^{143}$ the Supreme Court invalidated North Carolina's districting plan on the grounds that the boundaries of a majority-African American district were so bizarre that the plan impermissibly discriminated on the basis of race, in violation of the Equal Protection Clause. Among the numerous criticisms

137. See Pierre Schlag, Rules and Standards, 33 UCLA L. ReV. 379 (1985); Kathleen M. Sullivan, The Supreme Court, 1991 Term-Foreword: The Justices of Rules and Standards, 106 HARV. L. REV. 22 (1992).

138. Mark Tushnet, Rethinking the Dormant Commerce Clause, 1979 WIS. L. REV. 125, 150.

139. See City of Philadelphia v. New Jersey, 437 U.S. 617 (1978).

140. Pike v. Bruce Church, Inc., 397 U.S. 137, 142 (1970).

141. See Julian N. Eule, Laying the Dormant Commerce Clause to Rest, 91 YALE L.J. 425, 479 (1982); Daniel A. Farber, State Regulation and the Dormant Commerce Clause, 3 CONST. CommenT. 395, 399 (1986); Lawrence, supra note 135, at 397-99 (1998); Tushnet, supra note 138, at 15056.

142. See Farber, supra note 141, at 414 ("Because the outcomes of the [dormant Commerce Clause] cases are so unpredictable, the doctrine may well have a chilling effect on legitimate state regulation."); Lawrence, supra note 135, at 398 ("The lack of a coherent dormantcommerce-clause doctrine leaves individual States with much uncertainty about how far they may go in regulating activities that might implicate interstate commerce .... A State that is uncertain about the limits of its authority in regulating activities that might affect interstate commerce may be hesitant to enact novel and possibly visionary laws out of fear that they will be struck down in court.").

143. 509 U.S. 630 (1993). 
directed at the Shaw opinion was the argument that the Court's "I know it when I see it"144 approach was a recipe for confusion. Under this uncertain standard, two critics wryly observed, "each decade will inaugurate a new impressionistic course of litigation, presumably following the developmental structure of the animal kingdom, over the proper shape of districts . . . . [S] nakeline districts would clearly fail, but 'bug-splats' might stay on the margin, and even amoeboid- or octopus-shaped districts may survive." 145 Subsequent Supreme Court decisions have generally failed to add much clarity or certainty to the doctrine. ${ }^{146}$

Many areas of constitutional doctrine are, of course, unclear at the moment that the courts first start to engage with the relevant problems. Often the doctrine becomes clearer over time, as a body of precedents accumulates and the courts refine and clarify the nature of the tests they will apply. ${ }^{147} \mathrm{But}$, as the dormant Commerce Clause, redistricting, and numerous other possible examples illustrate, some doctrinal areas stubbornly resist this sort of clarification. As noted above, the failure of courts to achieve greater doctrinal clarity over time is usually viewed as imposing significant social costs.

Without minimizing the problems that doctrinal uncertainty can create, this Article's analysis of enactment costs as a screening mechanism suggests a potential benefit to this sort of unpredictability. The argument goes something like this: the enactment of any legislation entails opportunity costs for the members of the enacting coalition, who bear these costs regardless of whether the legislation ultimately goes into effect. Enacting legislators may accrue some benefits that are independent of whether a statute is upheld, but in most cases a sizeable fraction of the political and ideological benefits of passing legislation

144. Id. at 646-47; see also Karcher v. Daggett, 462 U.S. 725, 755 (1983) (Stevens, J., concurring) ("One need not use Justice Stewart's classic definition of obscenity - 'I know it when I see it' - as an ultimate standard for judging the constitutionality of a gerrymander to recognize that dramatically irregular shapes may have sufficient probative force to call for an explanation.").

145. T. Alexander Aleinikoff \& Samuel Issacharoff, Race and Redistricting: Drawing Constitutional Lines After Shaw v. Reno, 92 MiCH. L. ReV. 588, 624 (1993); see also Pamela S. Karlan \& Daryl J. Levinson, Why Voting Is Different, 84 CAL. L. ReV. 1201, 1212-13 (1996) (discussing the unpredictability of the Shaw standard).

146. See Pamela S. Karlan, Still Hazy After All These Years: Voting Rights in the Post-Shaw Era, 26 Cumb. L. Rev. 287, 287-89, 301-04 (1996); Karlan \& Levinson, supra note 145, at 1213 \& n.64, $1215,1226$.

147. See Ethan Bueno de Mesquita \& Matthew Stephenson, Informative Precedent and Intrajudicial Communication, 96 AM. POL. SCI. REV. 755 (2002). Sometimes, however, doctrine can get less predictable over time, or move in cyles between clarity and vagueness. See Carol M. Rose, Crystals and Mud in Property Law, 40 STAN. L. ReV. 577 (1988) (making this point with respect to property law). 
will be realized only if the legislative proposal becomes and remains valid law. When any individual legislator decides whether she will invest effort in passing a statute, she will compare the costs and benefits of enactment. The legislator will discount the present value of these benefits, however, if she cannot be sure whether the courts will uphold the statute. The less likely the courts are to sustain the statute, the lower the net benefits to the legislator of passing it. Therefore, as the probability of judicial acceptance drops, the higher the anticipated benefits of the statute would have to be to justify enacting it.

Because of this, doctrinal unpredictability is another way that courts can raise the legislature's enactment costs. In the enactment cost manipulation strategies discussed in previous sections, judicial doctrine increased enactment costs by conditioning approval of a constitutionally problematic policy on whether the government engaged in some costly activity-spending money, devoting time or political capital to more careful drafting or providing the right kind of legislative history, and so forth. In contrast, doctrinal uncertainty makes judicial approval probabilistic rather than conditional. But probabilistic approval, like conditional approval, can lower the expected net benefits of constitutionally problematic actions without precluding the possibility of such actions altogether.

This is simply a restatement of the "chilling effect" criticism of doctrinal unpredictability: uncertainty about whether a statute will be upheld reduces the expected net benefits of passing the statute (relative to the net benefits in the case in which the statute would certainly be upheld), but does not change the costs of enactment. ${ }^{148}$ Of course, doctrinal uncertainty increases the expected benefits of enacting a statute when the comparison is to a world in which the statute is certain to be struck down. ${ }^{149}$ The important point is that, by varying the probability with which a given statute will be upheld, the court can vary the effective enactment costs associated with that statute. Doing so will have a screening effect, because the legislature is more likely to invest the time and effort in passing a statute of uncertain constitutionality if the benefit of the statute to the enacting coalition is high.

To illustrate with a stylized example, imagine a state legislature considering a statute that would incidentally burden interstate commerce. Imagine that the enactment cost for this statute, to a representative legislator in the potential enacting coalition, is 3 units of utility. Let us suppose further that there is a $20 \%$ ex ante probability that this statute will have a very large positive effect on legitimate state interests; if so, the statute is worth 10 units of utility to the

148. See supra note 142 and accompanying text.

149. See Lawrence, supra note 135 , at 398-99. 
enacting legislature. There is also an $80 \%$ probability, however, that the benefits will turn out to be more modest, worth only 4 units of utility to the legislature. Let us also assume that the legislature knows whether the statute has high or moderate benefits before enacting it. Because the value of the statute (4 or 10) exceeds the enactment cost (3) even in the case in which the statute has lower benefits, the legislator would always prefer enactment, absent other considerations.

Now, consider the problem from the reviewing court's perspective. Assume that the court views the legislature's interests as legitimate, but the court also believes that the state legislature systematically undervalues the constitutional interest in preserving an unfettered national market. Stipulate that the statute in question would impinge on this constitutional interest, and the court views this impingement as imposing a cost equal to 5 units of utility. Furthermore, the state legislature does not internalize this utility loss. Thus, if the court upholds the statute, it would receive 5 net units of utility (10 minus 5 ) if the statute has high benefits, while the court's payoff from upholding the statute would be -1 ( 4 minus 5 ) if the benefits of the statute are more modest.

If the court knew the true benefits of the statute, it could condition its ruling on that information. But the court may not be able to make that assessment. If the uninformed court had to choose between upholding the statute and striking it down, the court would uphold the statute. The reason is that the expected value of the statute to the court is 0.2 units of utility: there is a $20 \%$ chance that the statute is worth 5 , and an $80 \%$ chance that it is worth -1 . The 0.2 units of expected utility the court gets if it upholds the statute are better than the zero expected utility the court gets if it strikes the statute down. The state legislature, of course, will pass the statute regardless of whether the benefits are high or low, given that it can anticipate a net utility payoff of 1 (4 minus 3 ) if the statute's benefits are low and 7 (10 minus 3 ) if those benefits are high.

Now suppose that the court can commit in advance to an "unpredictable" legal doctrine. In particular, suppose that under this doctrine, there is a $50 \%$ chance that the statute in question would be upheld, but there is also a $50 \%$ chance that the court would decide it violates the dormant Commerce Clause. In this case, the legislator's expected utility from passing a statute with high benefits is 2 units of utility: the legislator bears a cost of 3 up front, and has a $50 \%$ chance of realizing a gain of 10 . So, if the statute has high value, the legislator still views it as worth passing, even though there is a $50 \%$ chance that the court will strike it down. If the statute has more modest benefits, however, the legislator would not be willing to pass the statute because the net utility payoff of doing so is -1 : passing the statute requires paying an enactment cost of 3 in exchange for a $50 \%$ chance of realizing a gain of 4 . 
Because the only statutes that reach the court under these conditions are those that have high benefits, the court would prefer ex post to uphold the statute in all cases. By assumption, the court cannot do so because it has committed itself to applying a doctrine that will invalidate the statute half the time. ${ }^{150}$ The court's commitment to this unpredictable legal doctrine gives it an expected utility payoff of 0.5 : in the $80 \%$ of cases in which the statute has only moderate benefits, the court gets its status quo payoff of zero; in the $10 \%$ of cases in which the statute has high benefits but the court strikes it down, the court also receives a payoff of zero; in the $10 \%$ of cases in which the statute has high benefits and the court upholds it, the court realizes a net utility payoff of 5. Thus, the expected utility to the court when it commits to an unpredictable doctrine (o.5) is greater than its expected utility payoff when it simply makes its best (predictable) choice ex post (0.2).

The reason for this is that the uncertainty of judicial doctrine has a more powerful deterrent effect on the legislature for low-value statutes than for high-value statutes. Running the risk of judicial reversal is more worthwhile to the legislature when the statute has a higher value. In the stylized example discussed above, the court's best choice would be to commit to striking down legislative enactments with a $25 \%$ probability. A $75 \%$ chance that a statute is upheld is just small enough that the legislature would not enact a statute unless it has high rather than low benefits. So, the court's expected utility would be 0.75 (the $20 \%$ probability of a high-value statute times the $75 \%$ probability the statute is upheld times 5 net units of utility) - more than three times higher than the 0.2 units of expected utility the court would realize if it followed the ex post optimal strategy of upholding the statute $100 \%$ of the time.

The foregoing argument implies judicial behavior that appears perverse, at least at first blush. The only cases the court hears are those in which the statute's constitutional costs are outweighed by legitimate government interests, yet the court strikes down a large number of them. Furthermore, the court's decisions as to which statutes it will uphold and which it will strike down seem totally haphazard - which, in fact, they are, at least in the stylized version of the argument. An ex post evaluation might well conclude that the court's behavior was inexplicable and unjustifiable. Such a conclusion, however, might be too quick. If the court behaved differently-for example, if it were willing to uphold all statutes in the relevant class - the mix of statutes that the legislature would enact might change considerably. As the above example illustrates, such a change could lead to results that are systematically

150. If this were not true, screening at the legislative stage would not occur. This underscores how central the court's ex ante commitment to an unpredictable legal doctrine is to the structure of this argument. 
worse for the court when considered in the aggregate. Thus, doctrinal unpredictability, whatever its other costs, may be useful as a way to raise legislative enactment costs relative to anticipated statutory benefits.

The above argument is subject to a number of important qualifications and limitations. Foremost among these is the fact that the argument works only if the court can credibly commit itself to a doctrinal framework that is unpredictable at the point of application. Put another way, the court must be able to commit itself to striking down some number of legislative enactments, despite the fact that, ex post, the court would prefer that these enactments be upheld. The credible commitment problem applies to most versions of the enactment cost strategy, but the problem may be particularly acute in the context of a commitment to strike down some proportion of legislative enactments at random.

A second important qualification is that introducing uncertainty as to whether the court will uphold a legislative enactment does not always improve the court's expected utility, even when the four assumptions described in Part I hold. For one thing, the court must correctly calibrate the degree of doctrinal uncertainty. For another, even though doctrinal uncertainty improved the court's utility in the stylized example developed above, it would be easy to construct an example in which the court does just as well, or better, by always upholding or always rejecting a given type of legislation. The desirability of the strategy of doctrinal unpredictability depends on the probability distribution of the possible statutory benefits. Speaking informally, some degree of doctrinal unpredictability is likely to be desirable when there is a high probability that the statute has low value for the legislature and negative value for the court, but there is some probability that the statute has sufficiently high value that its ex ante net expected value from the court's perspective is positive. In this set of cases, the court can do better by rejecting statutes at random with some positive probability, as this will deter the legislature from passing the statute unless it is high-value.

Finally, the costs of unpredictable constitutional doctrine may often outweigh any screening benefits that unpredictability may create. ${ }^{151}$ Just as the deadweight social costs of judicial doctrines that increase enactment costs directly may outweigh the benefits of such doctrines, this may also be the case for doctrinal approaches that commit the court to some degree of unpredictability. That said, understanding the potential benefits of unpredictability as a screening device may provide a partial explanation for why certain areas of judicial doctrine are more resistant to clarification and

151. See, e.g., Posner \& Vermeule, supra note 133, at 1022. 
consistency than would otherwise seem optimal. The courts may recognize the virtues of predictability and clarity, but they may also see virtues in keeping the legislature a bit uncertain about which policies will pass constitutional muster, especially when the best clear rule the court could come up with would allow the legislature to promulgate large numbers of policies that the court, if fully informed, would view as unconstitutional.

\section{CONCLUSION}

This Article has advanced two central claims. First, Part I argued that under certain conditions, reviewing courts may implement constitutional guarantees more effectively by crafting doctrines that raise the costs to government decisionmakers of enacting constitutionally problematic policies. When the conditions described in Part I are satisfied, this enactment cost strategy has distinct advantages over both case-by-case balancing approaches and absolute, categorical rules that designate certain types of government action as prohibited or permitted. Second, Part II attempted to show that, while few if any judicial doctrines are explicitly and consciously designed with the primary purpose of raising legislative enactment costs, many doctrines in fact have that effect. Thus, the enactment cost approach to judicial regulation of constitutionally problematic government activity may be more widespread than it would at first appear, and certain doctrinal approaches may be justified on enactment cost grounds even if these doctrines were not developed explicitly with that purpose in mind. At the very least, federal courts already have the doctrinal resources to implement such a strategy, if they choose to do so.

The fact that an enactment cost strategy may be effective under some circumstances does not mean, however, that existing doctrines are well suited to this function. Indeed, given that few if any existing doctrines were designed with the express purpose of manipulating legislative enactment costs, it would be quite surprising if it turned out that all these doctrines served this function well. Part of the point of this Article is to suggest how consideration of the screening functions served by judicial enactment cost manipulation may lead to productive suggestions for doctrinal reform. Such considerations are obscured, however, by adherence to the view that constitutional doctrine is only about marking out the boundaries of permissible government action rather than about creating incentives that protect constitutional values indirectly. 